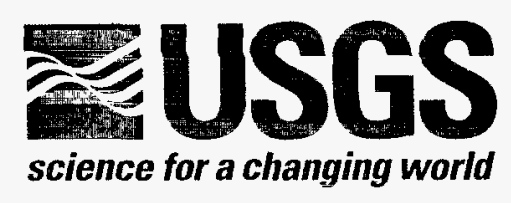

\title{
SIMULATED EFFECTS OF CLIMATE CHANGE ON THE DEATH VALLEY REGIONAL GROUND-WATER FLOW SYSTEM, NEVADA AND CALIFORNIA
}

\section{U.S. GEOLOGICAL SURVEY}

Water-Resources Investigations Report 98-4041

\section{RECEIVED \\ APR 261999 \\ OSTI}

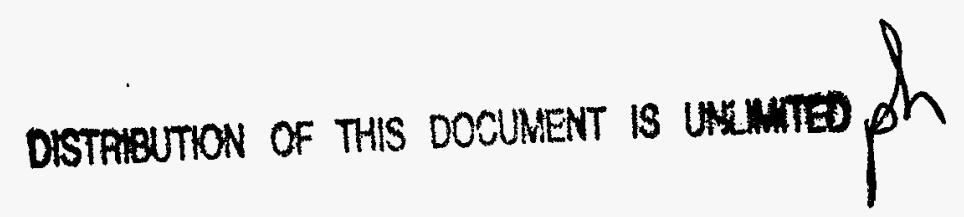

Prepared in cooperation with the

U.S. DEPARTMENT OF ENERGY,

NEVADA FIELD OFFICE, under

Interagency Agreement DE-Al08-97NV12033 


\section{DISCLAIMER}

This repor was prepared as an account of work sponsored by an agency of the United States Government. Neither the United States Governmeat nor any agency thereof, nor any of their employees, makes any warranty, express or implied, or assumes any legal liability or responsibility for the accuracy, completeness, or usefulness of any information, apparatus, product, or process disclosed, or represents that its use would not infringe privately owned rights. Reference berein to any specific commercial product, process, or service by trade name, trademark, manufacturex, or otherwise does not necessarily constitute or imply its endorsement, recommeadation, or favoring by the United States Government or any agency thereof. The views and opinions of authors expressed herein do not necessarily state or reflect those of the United States Governmeat or any agency thereof. 


\section{DISCLAIMER}

Portions of this document may be illegible in electronic image products. Images are produced from the best available original document. 


\section{Simulated Effects of Climate Change on the Death Valley Regional Ground-Water Flow System, Nevada and California}

By Frank A. D'Agnese, Grady M. O'Brien, Claudia C. Faunt, and Carma A. San Juan

U.S. GEOLOGICAL SURVEY

Water-Resources Investigations Report 98-4041

Prepared in cooperation with the U.S. DEPARTMENT OF ENERGY, NEVADA FIELD OFFICE, under Interagency Agreement DE-Al08-97NV12033 


\section{U.S. DEPARTMENT OF THE INTERIOR BRUCE BABBITT, Secretary}

U.S. GEOLOGICAL SURVEY

Charles G. Groat, Director

The use of firm, trade, and brand names in this report is for identification purposes only and does not constitute endorsement by the U.S. Geological Survey.

For additional information write to:

Chief, Earth Science Investigations Program Yucca Mountain Project Branch U.S. Geological Survey Box 25046, Mail Stop 421

Denver Federal Center Denver, CO 80225-0046
Copies of this report can be purchased from:

U.S. Geological Survey Information Services

Box 25286

Federal Center

Denver, CO 80225 


\section{CONTENTS}

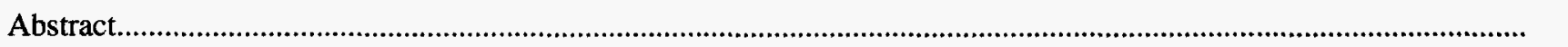

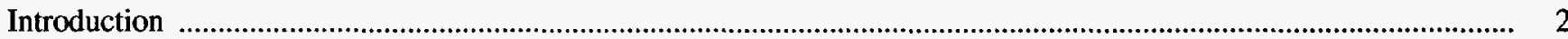

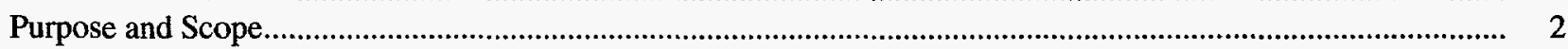

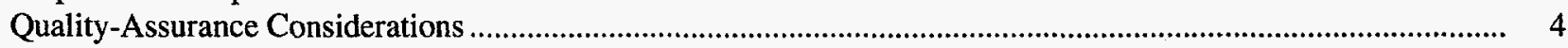

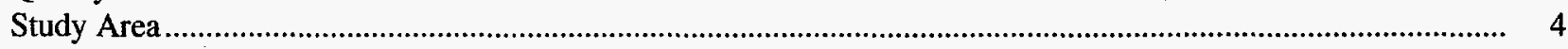

Past and Future Climate Conditions ......................................................................................................... $\quad 5$

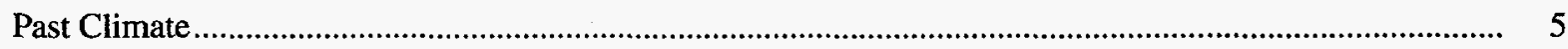

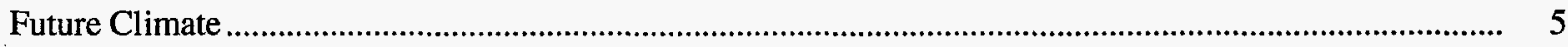

Estimated Past and Future Recharge Conditions................................................................................................... 7

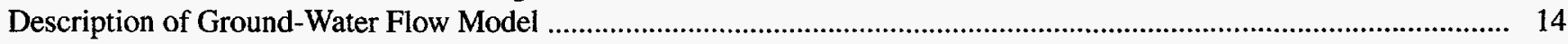

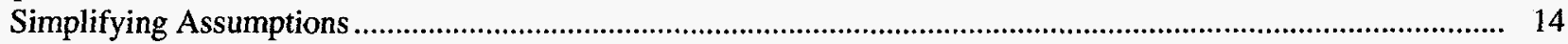

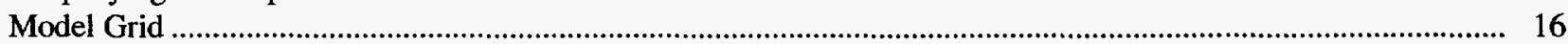

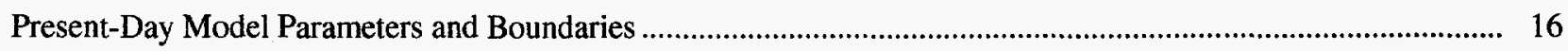

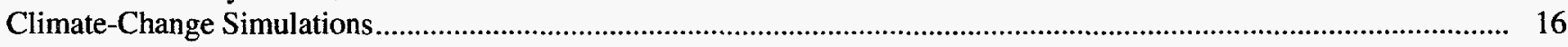

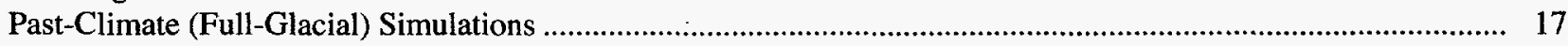

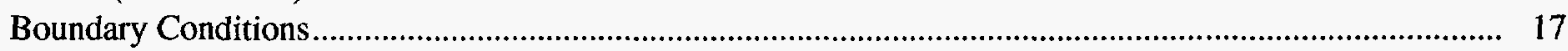

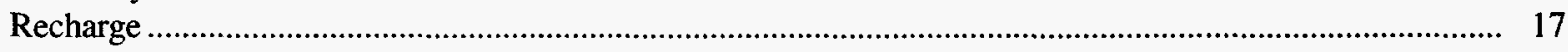

Conversion of Evapotranspiration Areas to Wetlands (Drains) ........................................................... 17

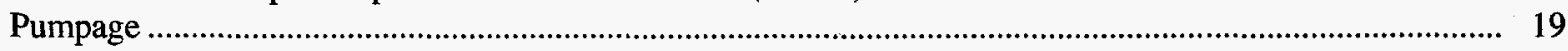

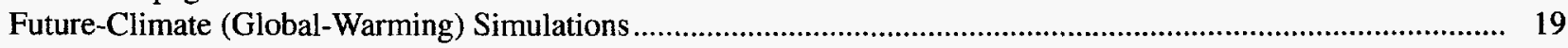

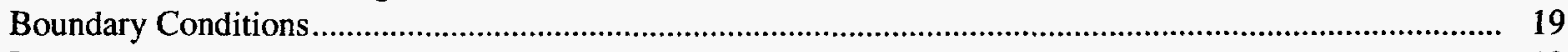

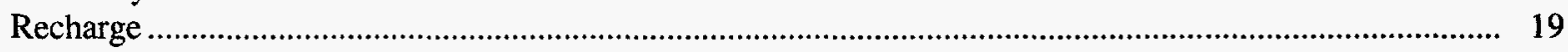

Conversion of Evapotranspiration Areas to Wetlands (Drains)....................................................................... 19

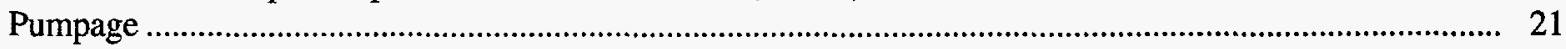

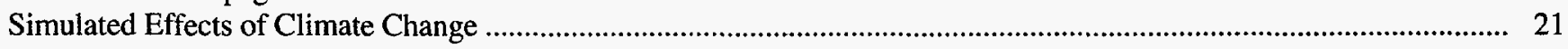

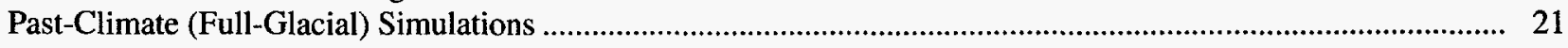

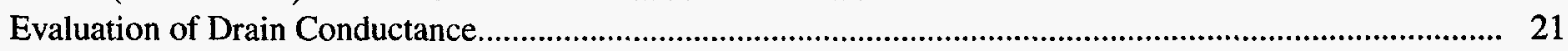

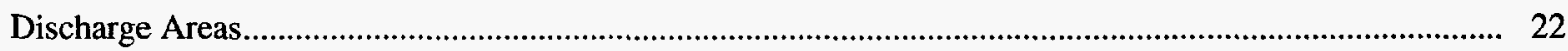

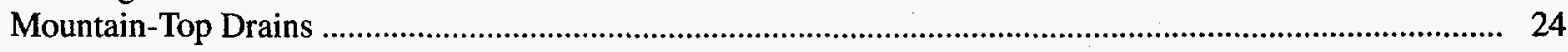

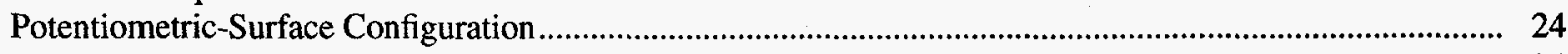

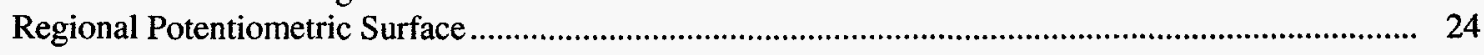

Yucca Mountain Potentiometric Surface …................................................................................ 27

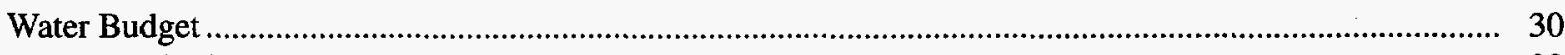

Future-Climate (Global-Warming) Simulations .............................................................................................. 30

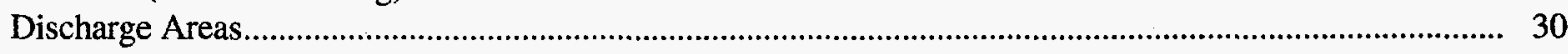

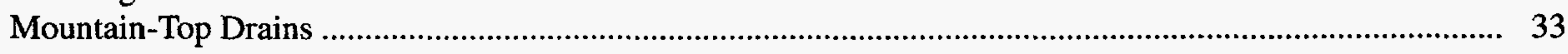

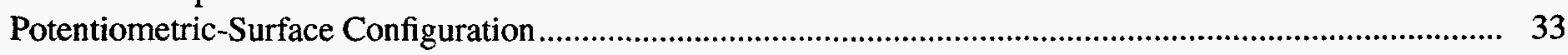

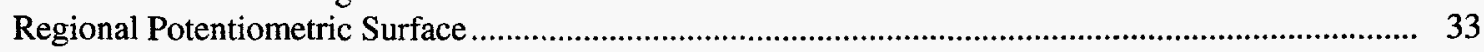

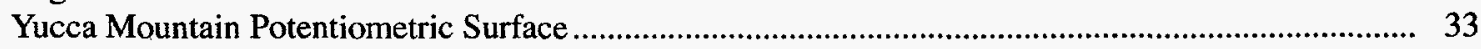

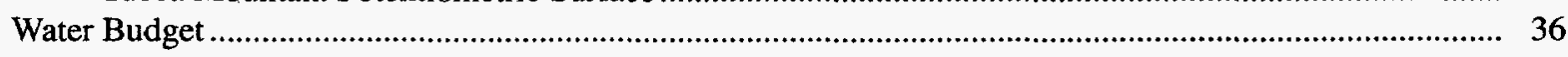

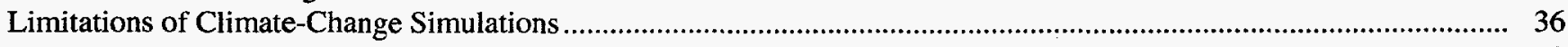

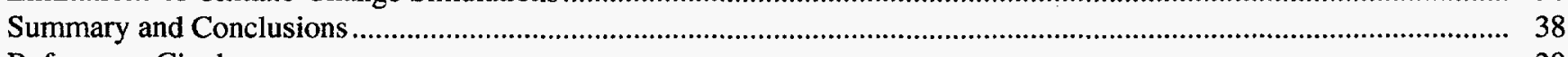

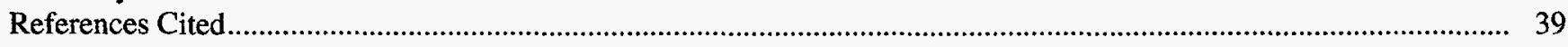

\section{FIGURES}

1-18. Maps showing:

1. Death Valley regional ground-water-flow system model domain .......................................................................

2. Location of lakes and wetlands that existed about 21,000 years ago................................................................. 6

3. Simulated recharge distribution for past-climate conditions about 21,000 years before present.............................. 9

4. Simulated recharge distribution for future-climate conditions.......................................................................... 10 


\section{FIGURES-Continued}

5. Simulated present-day recharge distribution

6. Difference between past-climate and present-day simulated recharge distributions ......................................... 12

7. Difference between future-climate and present-day simulated recharge distributions .........................................

8. Difference between past-climate and future-climate simulated recharge distributions ....................................... 15

9. Distribution of paleodischarge areas that were represented as constant- head cells and drains in the past-climate conditions ground-water-flow model simulation..................................................................................... 18

10. Distribution of constant-head cells and potential discharge areas that were represented as drains in the future-climate conditions ground-water-flow model simulation...

11. Distribution of drains and constant-head cells that were simulated as discharging during past-climate conditions

12. Simulated present-day climate potentiometric surface for model layer 1 ....................................................... 25

13. Simulated past-climate conditions potentiometric surface for model layer 1 and the difference between the past and present-day model layer 1 potentiometric surface.

14. Simulated past-climate conditions potentiometric surface for model layer 3 and the difference between the past and present-day model layer 3 potentiometric surface .......................................................................... 28

15. Simulated present-day potentiometric surface for model layer 3 ................................................................... 29

16. Distribution of constant-head cells and drains that were simulated as discharging during future-climate conditions

17. Simulated future-climate conditions potentiometric surface for model layer 1 and the difference between the future and present-day model layer 1 potentiometric surface.

18. Simulated future-climate conditions potentiometric surface for model layer 3 and the difference between the future and present-day model layer 3 potentiometric surface

\section{TABLES}

1. Net flux into and out of the model used to simulate past-climate conditions

2. Net flux into and out of the model used to simulate future-climate conditions

\section{CONVERSION FACTORS, VERTICAL DATUM, AND ABBREVIATIONS}

\begin{tabular}{rll}
\hline Multiply & By & To obtain \\
\hline meter $(\mathrm{m})$ & 3.281 & foot \\
millimeter $(\mathrm{mm})$ & 0.03937 & inch \\
kilometer $(\mathrm{km})$ & 0.6214 & mile \\
square kilometer $\left(\mathrm{km}^{2}\right)$ & 0.3861 & square mile \\
meter squared per day $\left(\mathrm{m}^{2} /\right.$ day $)$ & 10.76 & foot squared per day \\
cubic meter per day $\left(\mathrm{m}^{3} /\right.$ day $)$ & 35.31 & cubic foot per day \\
\hline
\end{tabular}

Degree Celsius $\left({ }^{\circ} \mathrm{C}\right)$ may be converted to degree Fahrenheit $\left({ }^{\circ} \mathrm{F}\right)$ by using the following equation:

${ }^{\circ} \mathrm{F}=\left(1.8 \times{ }^{\circ} \mathrm{C}\right)+32$.

Sea level: In this report "sea level" refers to the National Geodetic Vertical Datum of 1929 (NGVD of 1929) - a geodetic datum derived from a general adjustment of the first-order level nets of both the United States and Canada, formerly called Sea Level Datum of 1929.

Addtional abbreviation:

thousand years ago: ka 


\title{
Simulated Effects of Climate Change on the Death Valley Regional Ground-Water-Flow System, Nevada and California
}

\author{
By Frank A. D'Agnese, Grady M. O'Brien, Claudia C. Faunt, and Carma A. San Juan
}

\begin{abstract}
The U.S. Geological Survey, in cooperation with the U.S. Department of Energy, is evaluating the geologic and hydrologic characteristics of the Death Valley regional flow system as part of the Yucca Mountain Project. As part of the hydrologic investigation, regional, three-dimensional conceptual and numerical ground-water-flow models have been developed to assess the potential effects of past (full-glacial) and future (globalwarming) climates on the regional flow system. A simulation that is based on climatic conditions 21,000 years ago was evaluated by comparing the simulated results to observation of paleodischarge sites. Following acceptable simulation of a past climate, a possible future ground-water-flow system, with climatic conditions that represent a doubling of atmospheric carbon dioxide, was simulated.
\end{abstract}

The steady-state simulations were based on the present-day, steady-state, regional groundwater-flow model. The model area covered about 80,000 square kilometers between latitude $35^{\circ} \mathrm{N}$., longitude $115^{\circ} \mathrm{W}$. and latitude $38^{\circ} \mathrm{N}$., longitude $118^{\circ} \mathrm{W}$. and encompassed the Death Valley regional ground-water-flow system. The finitedifference model consisted of 163 rows, 153 columns, and 3 layers and was simulated using MODFLOWP. The grid was oriented northsouth and cells were of uniform size, with side dimensions of 1,500 meters. Three layers of uniform thickness represented ranges of 0-500, 500-1,250, and 1,250-2,750 meters below a generalized representation of an estimated water table.

Climate changes were implemented in the regional ground-water-flow model by changing the distribution of ground-water recharge. Globalscale, average-annual, simulated precipitation for both past- and future-climate conditions developed elsewhere were resampled to the model-grid resolution. A polynomial function that represents the Maxey-Eakin method for estimating recharge from precipitation was used to develop recharge distributions for simulation.

Results of climate-change simulations were evaluated by observing simulated discharge areas, water-level changes, potentiometric-surface configurations, and water budgets. During pastclimate conditions, recharge increased in most areas to produce a similarly shaped but higher regional potentiometric surface. A substantial change to the ground-water-flow system was the exclusion of underflow from Pahranagat Valley. The wetter conditions in the past-climate simulations provided sufficient ground water to maintain paleolake levels in the northern parts of the study area and in Death Valley. Ground-water discharge occurred at most of the predicted paleodischarge sites, which indicated that the recharge distributions used in the simulations were reasonable. Large hydraulic gradients in the region were preserved and enhanced under past-climate conditions. The water budget for the past-climate model indicated that recharge over the region increased by a factor of about six, relative to simulated present-day recharge. Under these 
extremely wet conditions, simulated water levels beneath Yucca Mountain rose between 60 and 150 meters, which is about 50 to $250 \mathrm{~m}$ below the level of the potential repository.

Under future-climate conditions, simulated recharge both increased and decreased, relative to present day. The configuration of the potentiometric surface changed only slightly to indicate depressions at discharging playas. These playas, however, were not simulated to have discharged as much water as they did during full-glacial climate conditions, and probably would not support perennial lakes. Several playa lakes in the northern and northeastern areas of the modeled area were simulated as discharging ground water. Under future-climate conditions, large hydraulic gradients were maintained and were enhanced in some areas. The water budget indicated that recharge throughout the modeled area increased by a factor of about 1.8 , relative to simulated present-day recharge. Under these climatic conditions, simulated water levels beneath Yucca

Mountain rise less than 50 meters, which is about 50 to $350 \mathrm{~m}$ below the level of the potential repository.

Substantial limitations exist when evaluating the effects of climate change on the Death Valley regional ground-water-flow system by use of numerical modeling. Therefore, the simulated effects of climate changes should be considered conceptual in nature and should be used only to describe potential relative effects on the regional ground-water-flow system.

\section{INTRODUCTION}

A mined, geologic, high-level nuclear-waste repository is being considered to isolate spent nuclear fuel from energy-producing nuclear reactors across the country. Yucca Mountain, which is on and adjacent to the Nevada Test Site in southwestern Nevada, is being studied as a potential site for such a repository (fig. 1). The U.S. Geological Survey, in cooperation with the U.S. Department of Energy under Interagency Agreement DE-AI08-97NV12033, is evaluating the geologic and hydrologic characteristics of this site as part of the Yucca Mountain Project. Because of the potential for radionuclides from such a repository to be transported by ground water to the accessible environment, the ground-water-flow system is being characterized. As a part of these investigations, regional three-dimensional conceptual and numerical groundwater-flow models have been developed. Based on the numerical ground-water-flow models, the potential effects of full-glacial and global-warming climates on the regional flow system are being assessed. Waterlevel changes associated with these climate conditions are important due to their possible effect on the potential repository. Long-term climate changes are considered because the potential repository may have an operational life of thousands of years.

\section{Purpose and Scope}

The purpose of this report is to document model simulations that investigate the effects of climate changes on the Death Valley regional ground-waterflow system. Regional ground-water modeling studies conducted by the U.S. Geological Survey are part of the Yucca Mountain site-characterization project. Two climate conditions are investigated: (1) past conditions that represent a full-glacial climate; and (2) future conditions that represent a global-warming climate. The climate changes are simulated by estimating the ground-water recharge associated with changes in precipitation. Methods used to estimate rates and distribution of recharge are described. Simulated water-level changes in the region and near Yucca Mountain are discussed. Simulated changes in discharge areas and flow in the Yucca Mountain area also are discussed.

The scope of this study was determined by Department of Energy Yucca Mountain Project guidelines, which are summarized as follows:

(1) The study was limited to the Death Valley region (fig. 1);

(2) The present-day, steady-state, regional ground-water-flow model described by D'Agnese and others (1997) was the basis for the simulations;

(3) Past-climate information was based on paleoclimatic data that are interpreted to describe conditions that likely existed about 21,000 years ago (S.L. Thompson and others, National Center for Atmospheric Research, written commun., February 1996); and 


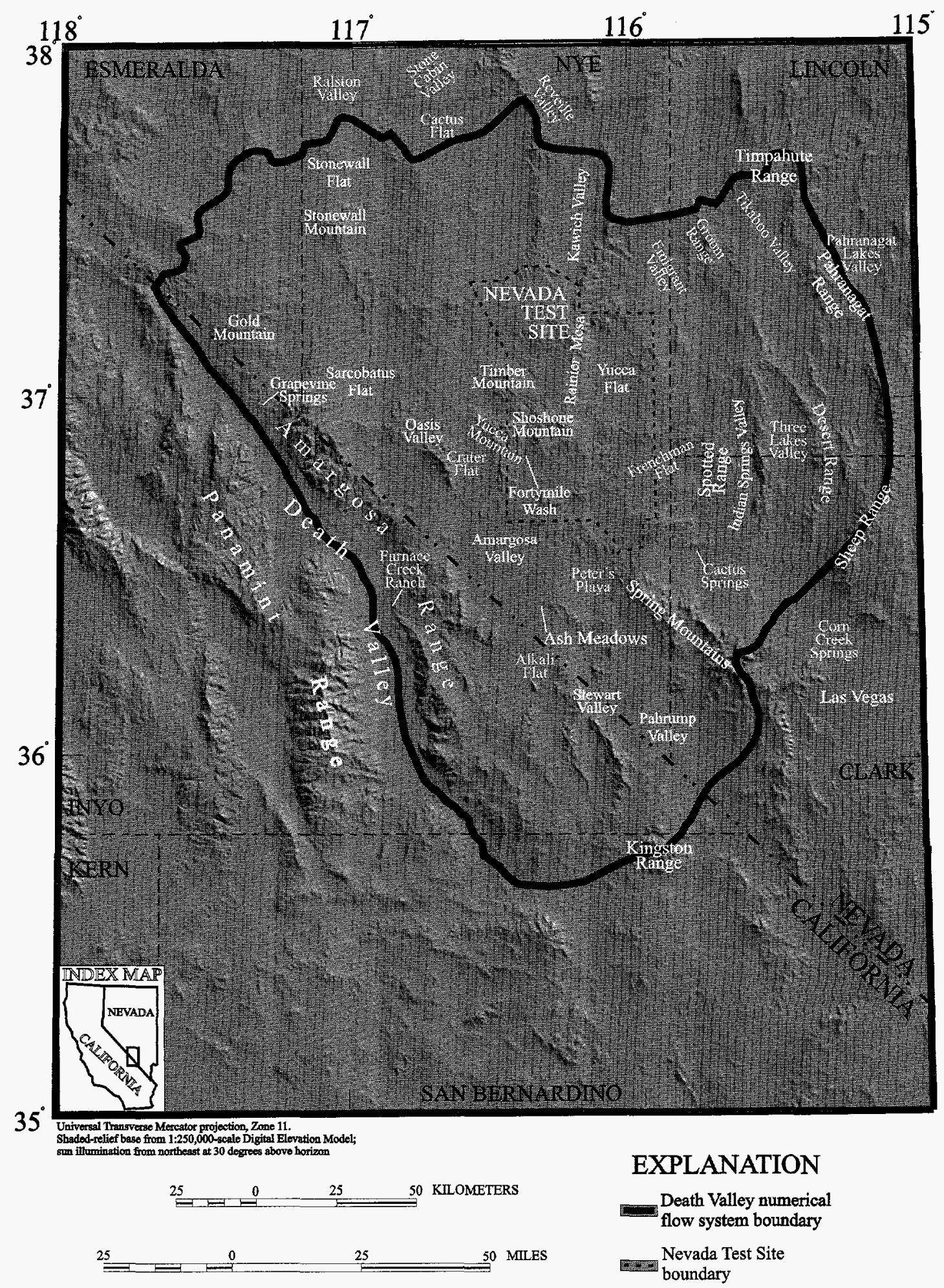

Figure 1. The Death Valley regional ground-water flow system model domain. 
(4) Future-climate information was based on predicted climatic effects that result from doubling present-day atmospheric concentrations of carbon dioxide (S.L. Thompson and others, National Center for Atmospheric Research, written commun., August 1996).

Several conditions mandated the simulation of the full-glacial 21,000 years ago (21 ka) climate conditions and doubling of atmospheric carbon dioxide $\left(\mathrm{CO}_{2}\right)$ concentrations climate conditions. The full-glacial 21 ka condition was chosen because of climate indicators available for this time period, which allowed the climate model to be validated. The cooler and wetter conditions present during the full-glacial $21 \mathrm{ka}$ were also considered to represent a reasonable potential wet climate that could occur in the future (R.M. Forester and others, U.S. Geological Survey, written commun., 1996). The doubling of atmospheric carbon dioxide $\left(\mathrm{CO}_{2}\right)$ condition was also considered to represent reasonable future-climate conditions.

Several alternative climate conditions could be considered to estimate the potential effect on the ground-water-flow system in the Yucca Mountain area. The wettest conditions that have existed in the Yucca Mountain area probably occurred during the Illinoian glacial stage about 140-170 ka (R.M. Forester, U.S. Geological Survey, oral commun., 1997). These wet climate conditions would represent a pre-historic worst-case condition for potential high water levels and thus highest recharge rates. Climate forcing conditions that were not simulated could occur in the future that would result in wetter conditions than estimated with a doubling of atmospheric $\mathrm{CO}_{2}$. Additional precipitation distributions could be developed on the basis of potential climate forcing. The simplest approach to developing additional climate conditions, however, would be to multiply present-day recharge by constant factors and simulate the effects on the ground-water-flow system. These alternative climate conditions were beyond the scope of this study.

\section{Quality-Assurance Considerations}

Because interpretations of model results may be used to assess the expected performance of a highlevel nuclear-waste repository, confidence in the reliability of data used in model construction and model evaluation is necessary. A quality-assurance program has been implemented by the Yucca Mountain Project to support the reliability of the data and interpretations of data.

Data used by the Yucca Mountain Project are classified as either qualified or nonqualified. Qualified data are defined as data acquired or developed for the Yucca Mountain Project under a Nuclear Regulatory Commission accepted quality-assurance plan or qualified in accordance with appropriate Yucca Mountain Project procedures. Developed data cannot be classified as qualified if derived from nonqualified data sources (U.S. Department of Energy, written commun., 1996).

Because of the regional scope of this report, data used in the construction of the hydrogeologic framework and ground-water-flow model were developed from published sources or obtained from publicly available sources. Nearly all these sources originated outside of the Yucca Mountain Project, or were obtained and published before the implementation of the project quality-assurance program. No qualified data, which are regional in scope, are available.

Therefore, no data presented in this report can be classified as qualified, and the results of the modeling are based entirely on nonqualified data. Model construction and review, however, were performed in accordance with accepted quality-assurance procedures and U.S. Geological Survey policy.

\section{Study Area}

The study area is bounded by $35^{\circ}$ and $38^{\circ} \mathrm{N}$. latitude and $115^{\circ}$ and $118^{\circ} \mathrm{W}$. longitude, covered about 80,000 square kilometers $\left(\mathrm{km}^{2}\right)$, and was chosen to include the Death Valley regional ground-water basin, first defined by Bedinger and others (1989). The Death Valley region is located along the border of southwestern Nevada and southeastern California. The boundary of the region was modified by D'Agnese and others (1997) for a regional groundwater-flow model (fig. 1). The ground-water basin is immediately west of the city of Las Vegas, Nevada, and includes parts of Esmeralda, Nye, Lincoln, and Clark Counties, Nevada, and Inyo and San Bernardino Counties, California. Yucca Mountain is located in about the geographic center of the region on the western border of the Nevada Test Site (fig. 1). 


\section{Past and Future Climate Conditions}

As part of evaluating the geologic and hydrologic characteristics of the Yucca Mountain site, the potential effects of climate change on the regional flow system are being assessed. Climate changes may affect the potential for radionuclides to be transported by ground water from the repository to the accessible environment. To simulate the effects of climate changes, the present-day, steady-state regional groundwater-flow model developed by D'Agnese and others (1997) was modified.

To assess the potential hydrologic effects of climate change, two basic simulations were performed. First, as a reasonableness check on the future-climate condition, a simulation that is based on past climatic conditions was evaluated by comparing simulated results to observed paleodischarge sites. The ground-water-flow system, which is based on climatic conditions about $21 \mathrm{ka}$, was simulated to represent ground-water flow under full-glacial conditions. Second, a possible future ground-water-flow system was simulated with climatic conditions that represented global warming.

\section{Past Climate}

The potential repository level is located about 200 to 400 meters $(\mathrm{m})$ above the present-day potentiometric surface. Evidence for higher saturated-zone water levels at some time in the past has been suggested on the basis of secondary mineral occurrences (Levy, 1991), strontium isotopic variations from borehole data (Marshall and others, 1993), and from hydrologic models that are based on assumed increased recharge (Czarnecki, 1985). Past-climate records from throughout the southern Great Basin demonstrate that episodes of higher effective moisture relative to present-day conditions have occurred. Ground-water discharge deposits commonly are exposed in the region (R.M. Forester and others, U.S. Geological Survey, written commun., 1996). Valleys that had evidence of ground-water discharge at about $21 \mathrm{ka}$ (using ostracode and physical and chemical sample data) were delineated from topographic maps (fig. 2) by R.M. Forester and others (U.S. Geological Survey, written commun., 1996). These areas are considered possible paleodischarge sites for the past-climate simulations.
During the late Pleistocene (40-12 ka), effective moisture was higher throughout the Death Valley region (R.M. Forester and others, U.S. Geological Survey, written commun., 1997). Higher effective moisture was a result of lower temperatures, with a consequent reduction in evapotranspiration, and higher precipitation. In the Death Valley region, increased effective moisture was manifested by lakes, perennial drainage systems, some large wetlands, and many small seeps and minor wetlands (fig. 2). Within the region, shallow (less than $50 \mathrm{~m}$ deep) lakes existed in the Emigrant, Gold Flat, and Kawich basins. Fortymile Wash, a major tributary, and the Amargosa River itself were probably perennial streams that helped supply the large Lake Manley in Death Valley. Wetlands such as those represented by the deposits at Cactus, Corn Creek, and Tule Springs were supported by discharge from both the ground-water and surfacewater systems. Increased recharge in the Spring Mountains and Sheep Range probably resulted in spring discharge from the alluvial fans at the foot of the mountain ranges. Under these climate conditions, discharge from all sources probably greatly exceeded that which occurred during historical times.

The deposits in northern Amargosa Valley (fig. 2) probably also represent an area of focused ground-water discharge during the last (40-12 ka) glacial period (R.M. Forester and others, U.S. Geological Survey, written commun., 1996). Discharge probably also occurred in Crater Flat. The State Line deposits show an interplay of surface flow and spring discharge similar to those at the deposits at Lathrop Wells. Paleodischarge records that are dated around 21 ka do not exist for Ash Meadows or Pahranagat Valley. Quade and others (1995) have identified and studied late Pleistocene wetland deposits in the Coyote Springs Valley. Extensive spring-discharge and wetland deposits are known from the Pahrump Valley, and according to Quade and others (1995), deposits from about 21 ka probably do exist there.

\section{Future Climate}

Descriptions of potential future hydrologic conditions are highly speculative. A human-induced worst-case future-climate condition that represents global warming was simulated with a doubling of present-day $\mathrm{CO}_{2}$ concentrations in the atmosphere that would result from burning all estimated reserves of petroleum and natural gas. Thompson and others 


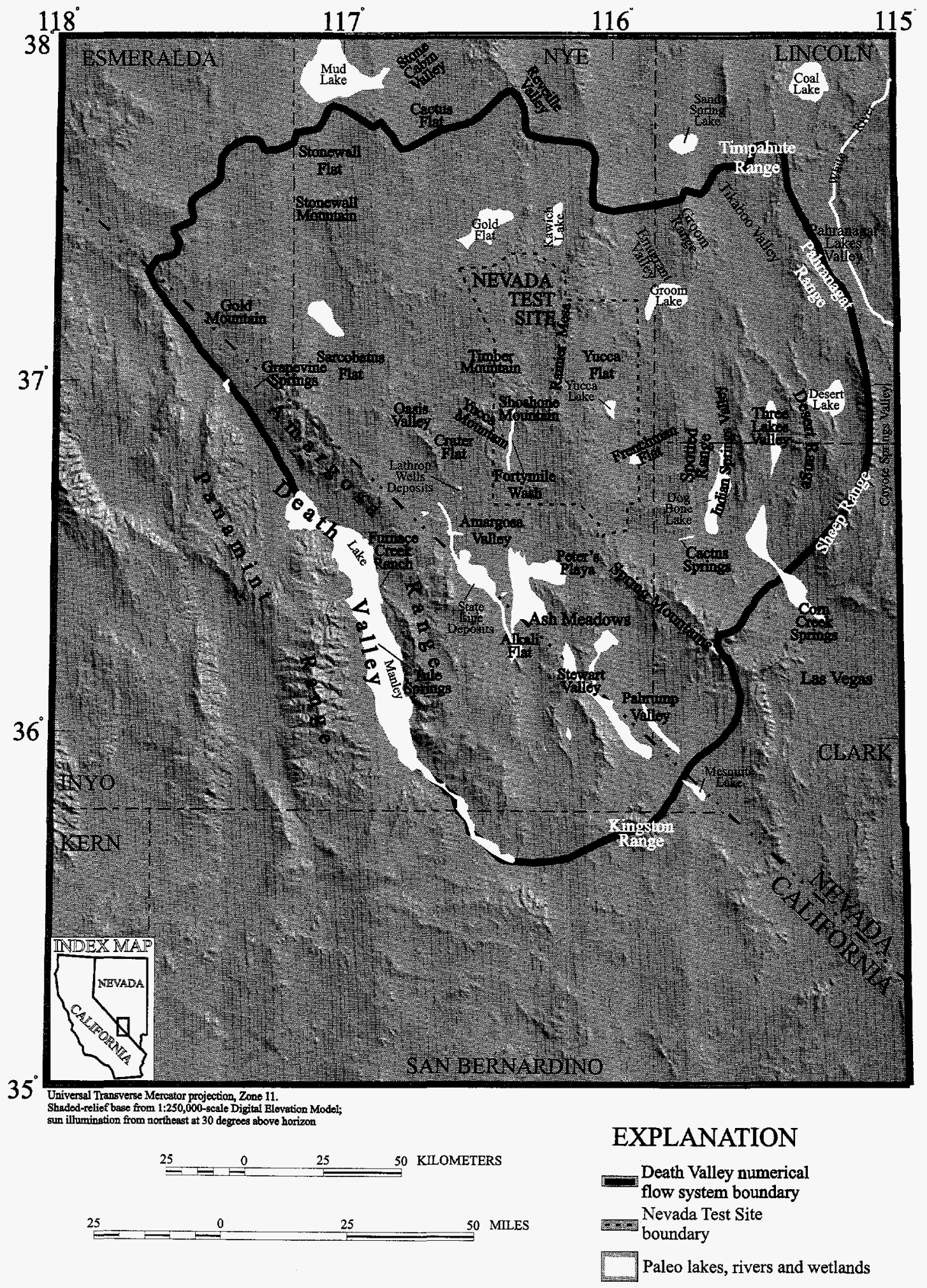

Figure 2. The location of lakes and wetlands that existed about 21,000 years ago, (R.M. Forester and others, U.S. Geological Survey, written commun., 1996). 
(National Center for Atmospheric Research, written commun., August 1996) developed a distribution of the average annual precipitation that would occur with this climate change. This distribution results in a hydrologic system that contains substantially less moisture than that which was simulated to have occurred at $21 \mathrm{ka}$.

\section{Estimated Past and Future Recharge Conditions}

Changes in ground-water recharge have a major effect on simulated changes in the regional groundwater-flow system. Increased precipitation during wetter climatic conditions will result in increased recharge to the ground-water-flow system. Distributions of recharge developed for this study relied on the Maxey-Eakin method (Maxey and Eakin, 1949). The potential errors associated with using this method for estimating regional recharge rates are discussed in detail in D'Agnese and others (1997).

The recharge distributions used in the past and future climate simulations were based on climate models developed by Thompson and others (National Center for Atmospheric Research, written commun., 1996). The modeling approach involved the use of nested global and regional climate models. A global circulation model (GCM) with 200 - to $600-\mathrm{km}$-grid spacing was used to capture the large-scale climatic forcing due to the Earth's orbit and changes in $\mathrm{CO}_{2}$ gas concentrations. A regional circulation model (RCM), centered over the Yucca Mountain area, with a 50-km-grid spacing was used to capture local climatic changes that are influenced by complex topographic features and surface characteristics. The GCM and RCM are considered as nested models because the initial and time-dependent boundary conditions for the RCM were based on climate simulations produced by the GCM.

The climate models are complex representations of the physical processes that affect climate change. Conservation of momentum, mass, and energy for air parcels are incorporated in the models. The main physical atmospheric processes, such as radiative transfer, cloud and precipitation formation, boundary layer physics, and surface physics, are accounted for in these models. Accurate predictions of climate change also require that the interaction between the atmosphere, oceans, and the cryosphere be represented, so the distributions of sea surface temperature, sea ice, and snow cover are included as model inputs.

The Thompson and others (National Center for Atmospheric Research, written commun., February 1996) climate models were tested to determine if the simulation results were reasonable. A comparison of present-day and paleoclimate simulations with known climate conditions validated the circulation models. These simulation results indicated that the RCM was providing an adequate representation of the climate conditions. The RCM was not designed to provide Yucca Mountain site-specific simulations, rather the results are representative of an area several grid cells across (100 to $200 \mathrm{~km}$ ).

Two climate conditions were simulated by Thompson and others (National Center for Atmospheric Research, written commun., 1996): a past, full-glacial climate that occurred about $21 \mathrm{ka}$, and a potential future climate that is represented by a doubling of atmospheric $\mathrm{CO}_{2}$. The RCM full-glacial conditions were simulated by using the GCM boundary conditions from $21 \mathrm{ka}$. Thompson and others (National Center for Atmospheric Research, written commun., 1996) concluded that these simulations were reasonable because, as expected, the simulated full-glacial climate was cooler and wetter than the present-day conditions. The recharge distribution used in the 21-ka ground-water-model simulations was based on the mean precipitation distribution over a 2 year period that was determined from these climate simulations. Based on the model's ability to reasonably reproduce the present-day and 21-ka climate simulations, it was determined that the nested modeling approach was adequate to provide future climate simulations.

A doubling of present-day atmospheric $\mathrm{CO}_{2}$ concentration was the forcing used in the future climate simulations. With the current rate of fossil fuel consumption it is expected that atmospheric $\mathrm{CO}_{2}$ concentrations will double within the next 100 years. In general, the future climate simulations resulted in a uniform temperature increase of 2-3 degrees Celsius in the Yucca Mountain area. Compared to present-day conditions, precipitation substantially increased during the winter season in California, and this effect extended into southern Nevada. The simulated future precipitation during the summer, however, decreased in southern Nevada. A 4-year average of simulated precipitation was used to estimate recharge for the ground-water-model simulations. 
The average annual precipitation maps developed by Thompson and others (National Center for Atmospheric Research, written commun., February 1996) were calculated on a $50-\mathrm{km}$ grid and required additional formatting prior to use in the ground-waterflow model. The present-day precipitation distribution developed by Thompson and others (National Center for Atmospheric Research, written commun., February 1996) was similar to present-day climate conditions and was used as the baseline precipitation. By using this baseline distribution and the results of the fullglacial climate model, a ratio of the full-glacial and the baseline precipitation distributions was developed. The ratio precipitation distribution was then multiplied by the average annual precipitation distribution used in the present-day regional ground-water-flow model. The resultant distribution, therefore, was the predicted distribution of average annual precipitation under fullglacial climate conditions. For use in the groundwater-flow simulations, these data were then resampled to a $1.5-\mathrm{km}$ grid coincident with the regional ground-water-flow model.

Next, a polynomial function that represents the Maxey-Eakin area-altitude relation for determining recharge from precipitation was applied (J.A. Hevesi and A.L. Flint, U.S. Geological Survey, written commun., January, 1996). While potential errors exist when using the Maxey-Eakin method to estimate regional ground-water recharge for even present-day conditions, the simple empirical relation of precipitation-to-recharge is adequate for estimating recharge under past or future climate conditions in simulations that are conceptual in nature. The Maxey-Eakin polynomial function was used to produce a grid-format map of recharge for the 21-ka climate. The grid-format map was resampled to the grid resolution of the regional flow model (fig. 3) and was used to produce the recharge array for the past-climate simulations

The simulated average annual precipitation map for future-climate conditions was based on doubling present-day atmospheric $\mathrm{CO}_{2}$ concentration (Thompson and others, National Center for Atmospheric Research, written commun., August 1996) and developed in the same manner as the past-climate precipitation distribution. The distribution of recharge used in the future-climate ground-water simulations (J.A. Hevesi and A.L. Flint, U.S. Geological Survey, written commun., June, 1997) was developed with a polynomial that represents the Maxey-Eakin method (J.A. Hevesi and A.L. Flint, U.S. Geological Survey, written commun., January, 1996). The recharge map, which is based on a doubling of present-day atmospheric carbon dioxide, was resampled to the grid resolution of the regional flow model (fig. 4) and was used to produce the recharge array for the futureclimate simulations.

The method used to determine recharge for the past-climate and future-climate simulations was different from the method used to determine recharge for the present-day simulation (D'Agnese and others, 1997) (fig. 5). A detailed discussion of how recharge was determined in the steady-state model is provided in D'Agnese and others (1997). The difference in approaches results in recharge rates being somewhat different in some parts of the model domain. The high rates and distribution of recharge in the Spring Mountains, for example, are represented quite differently in the present-day and in the future-climate simulations. The climate simulations do not result in a simple linear increase in recharge across the model domain, and the ground-water simulations that use the different recharge distributions do not result in simple linear increases in the potentiometric surface.

In addition to the changes caused by the differences in the methods for determining recharge, the climate conditions result in different recharge distributions than those used in the present-day model because of different precipitation patterns (figs. 6 and 7). The total volume of recharge simulated in both the pastclimate and future-climate simulations is greater than the simulated present-day recharge. The distribution of recharge, however, varies greatly between the different climate conditions.

The recharge rates in the past-climate simulation were generally higher than rates used in the present-day simulation. The biggest differences between past-climate and present-day recharge rates were in the Spring Mountains, Kingston Range, and Sheep Range, where past-climate recharge was more than $100 \mathrm{~mm} / \mathrm{yr}$ higher than present-day recharge (fig. 6). The Amargosa Range, Kingston Range, Spring Mountains, Sheep Range, Pahranagat Range, and the Timber Mountain-Rainier Mesa area had recharge rates that were at least $50 \mathrm{~mm} / \mathrm{yr}$ higher in the past-climate simulations than in present-day simulations (fig. 6). Most of the model domain in the pastclimate simulations had recharge rates that were 0 to $50 \mathrm{~mm} / \mathrm{yr}$ higher than in present-day simulations. The western part of the model domain, including Death Valley and the Sarcobatus Flat-Stonewall Mountain 

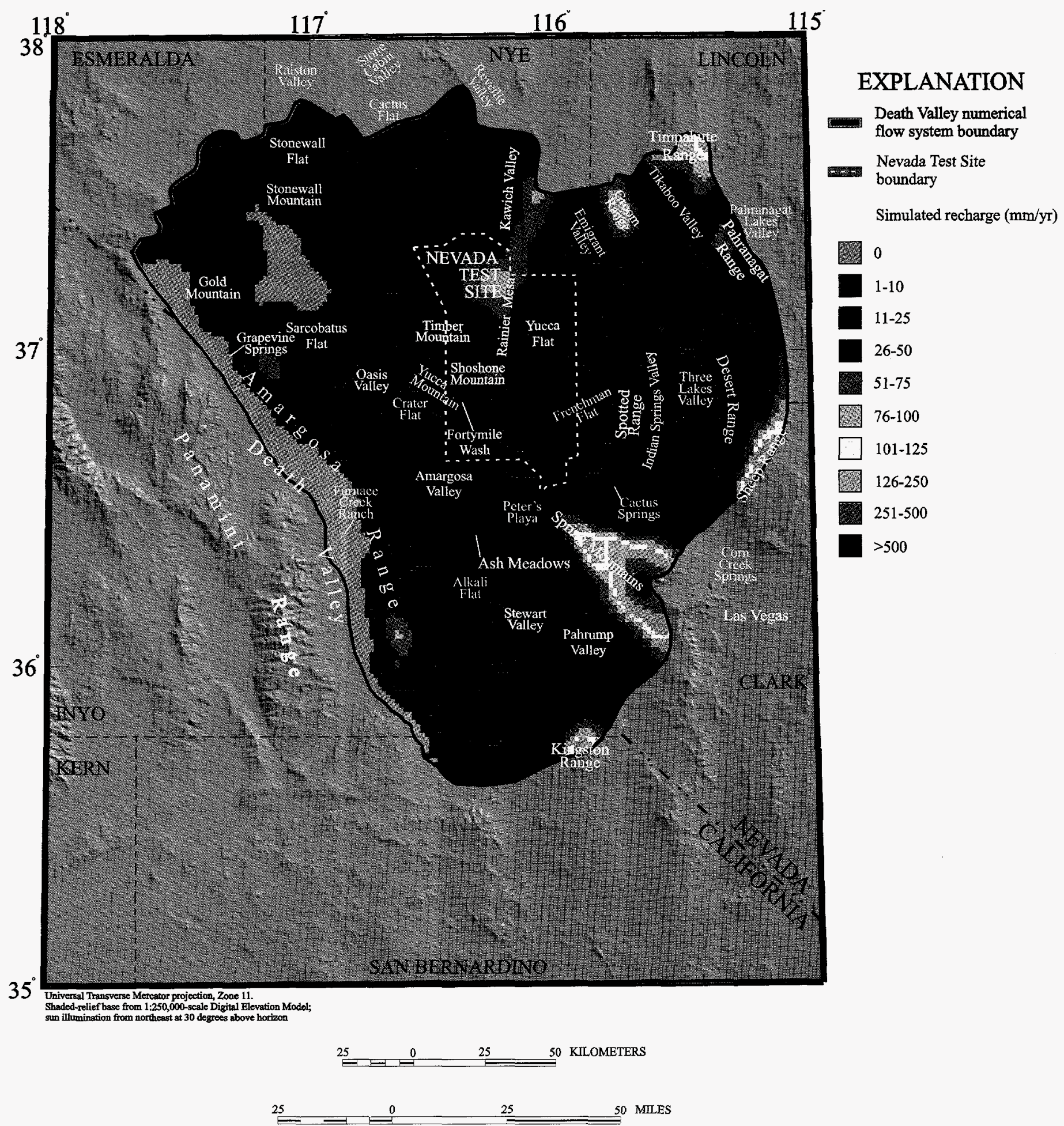

Figure 3. Simulated recharge distribution for past-climate conditions, 21,000 years before present. 


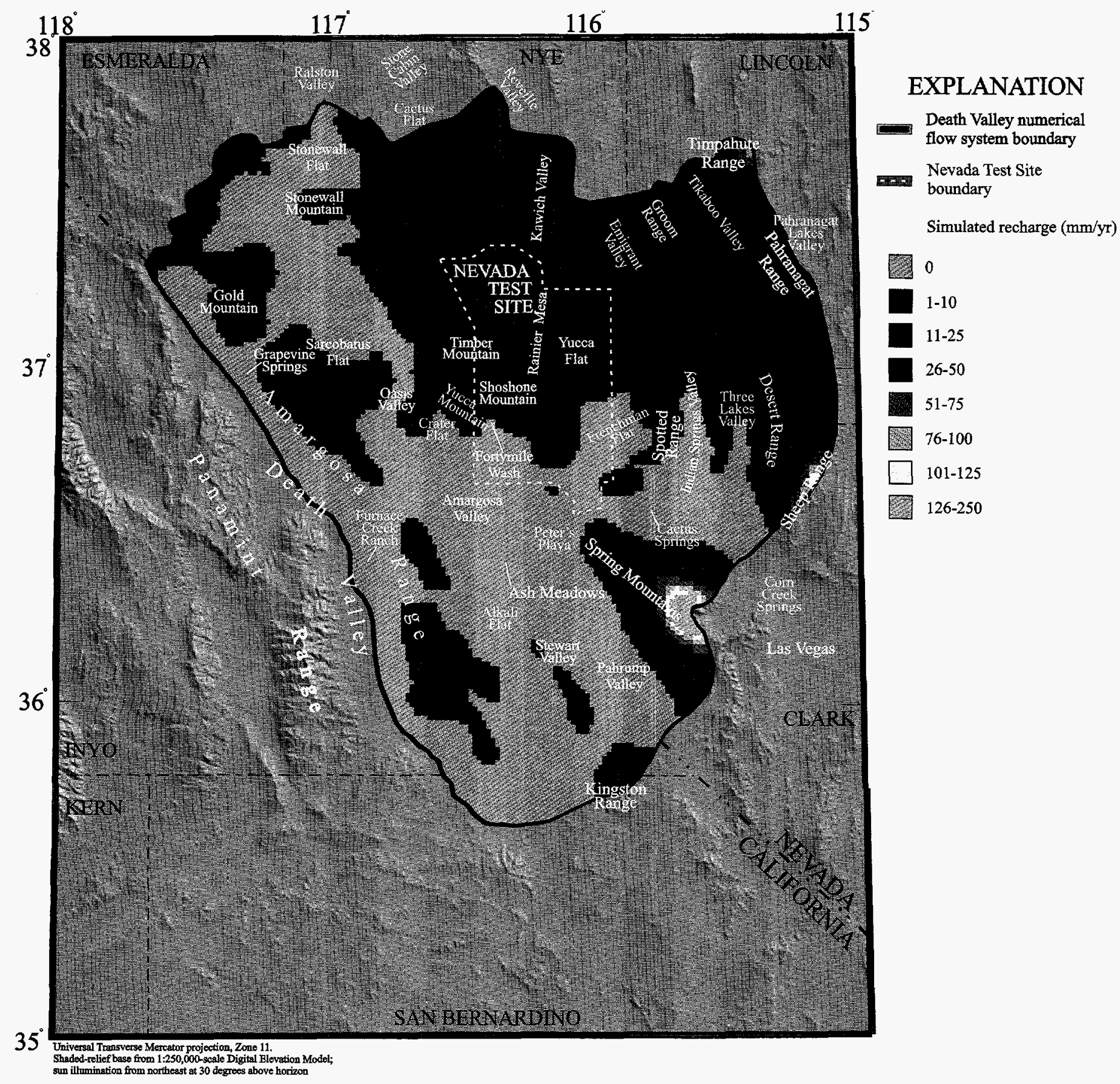

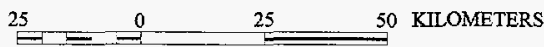

$25 \quad 0 \quad 25 \quad 50$ MILES

Figure 4. Simulated recharge distribution for future-climate conditions (doubling of present-day atmospheric carbon dioxide). 


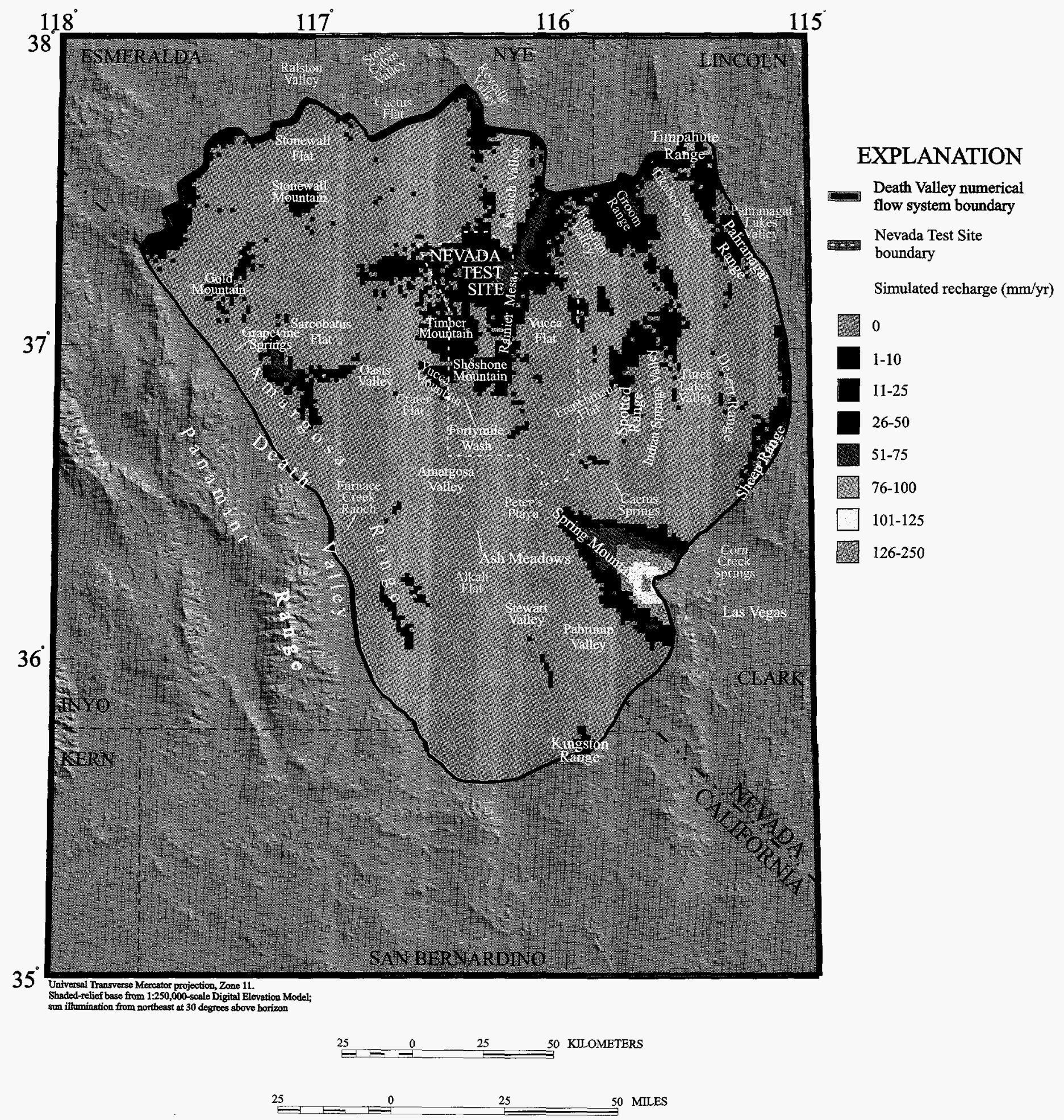

Figure 5. Simulated present-day recharge distribution (D'Agnese and others, 1997). 


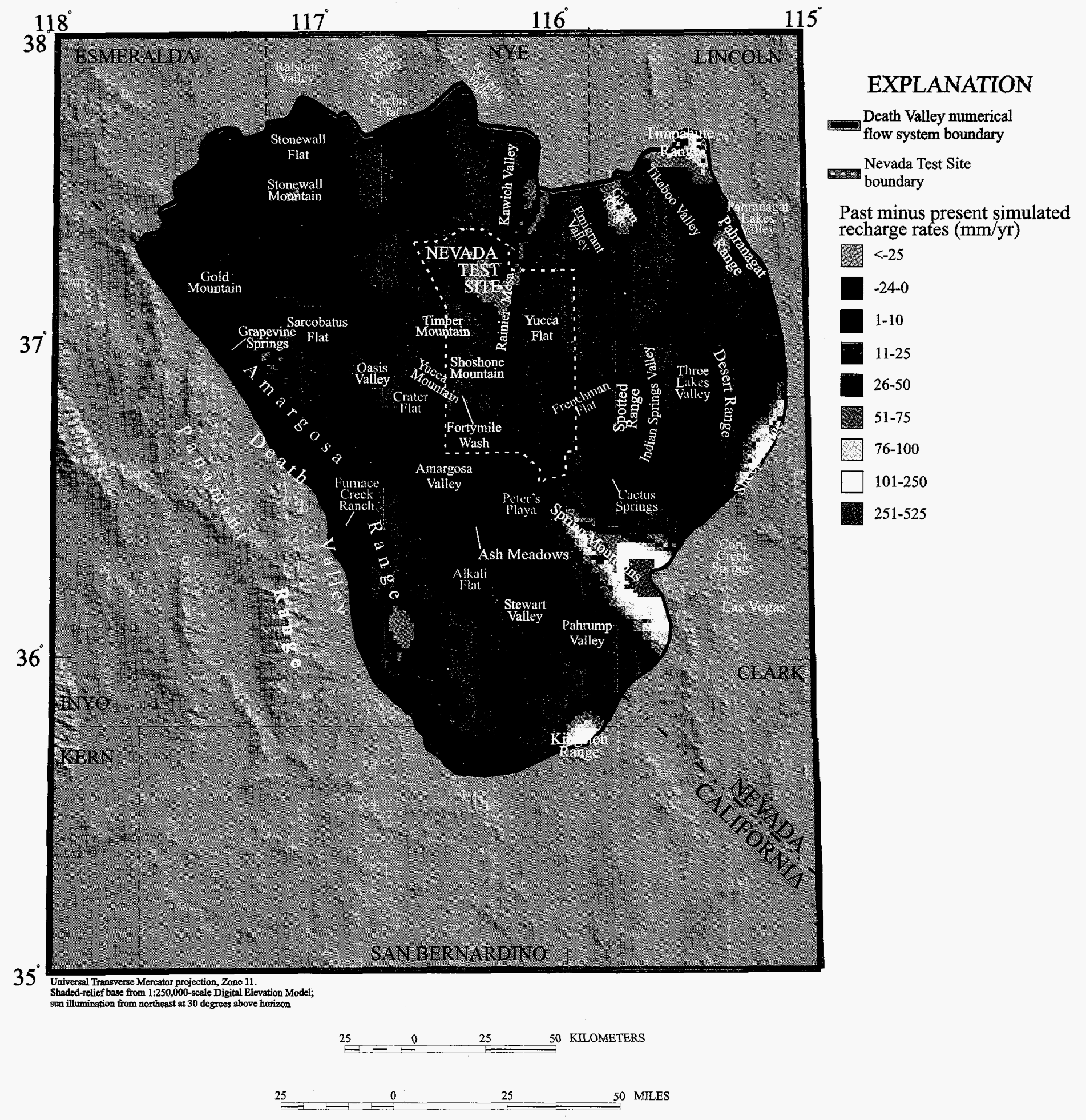

Figure 6. Difference between past-climate and present-day simulated recharge distributions. 


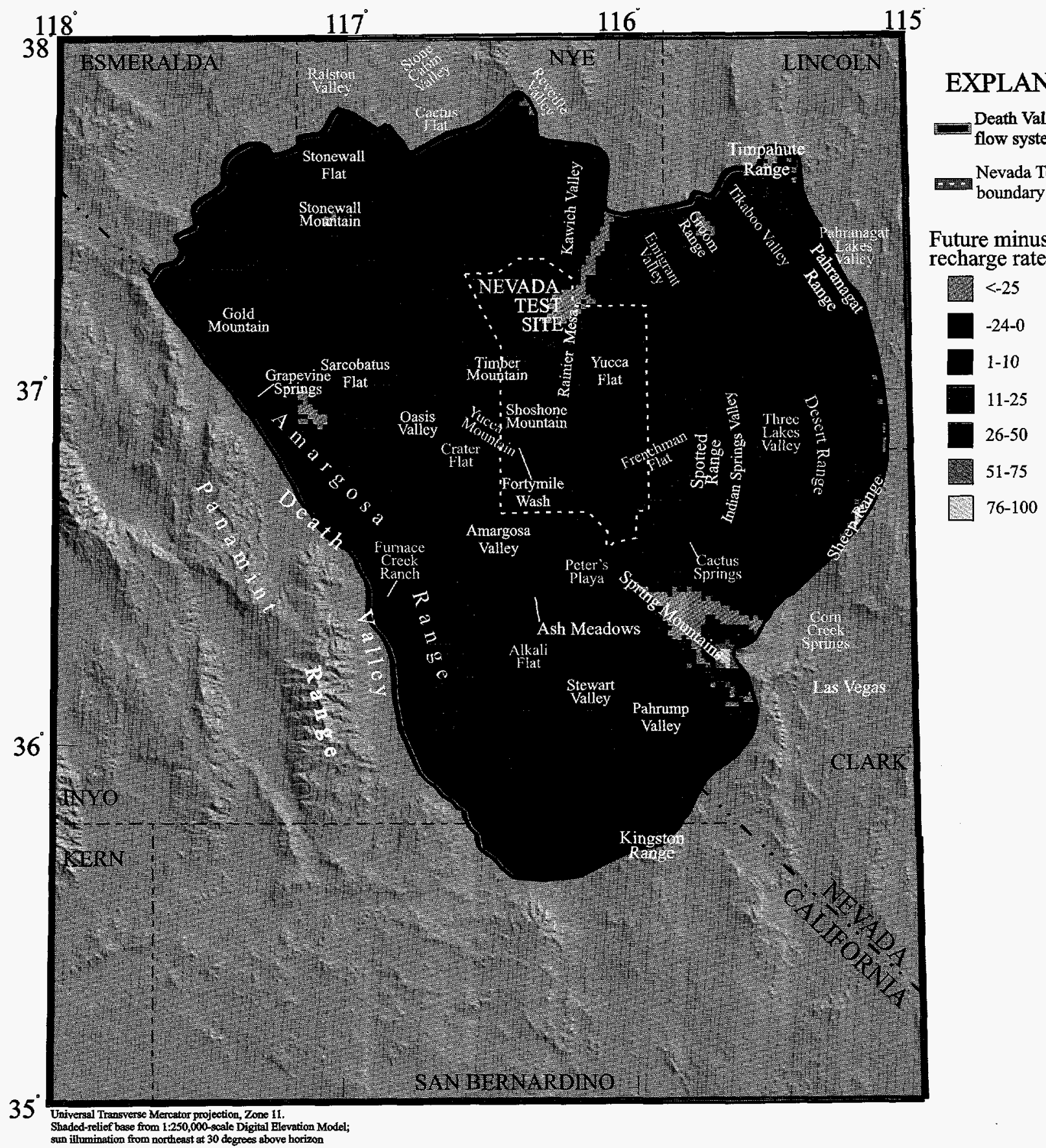

$\stackrel{25}{=} \stackrel{0}{-}-25 \quad$ SO KILOMETERS

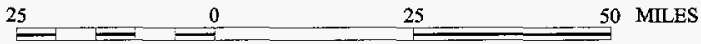

Figure 7. Difference between future-climate and present-day simulated recharge distributions. 
area, had recharge rates in the past-climate simulations that were less than in the present-day simulations (fig. 6).

Total recharge in the future-climate simulation was greater than in present-day simulations (figs. 7 and 8). Most of the north and northeast areas of the model domain had future-climate recharge rates that were greater than present-day recharge. Future-climate condition recharge rates also were generally greater than present-day simulated recharge in higher altitude areas, including Pahranagat Range, Kingston Range, Spring Mountains, and Sheep Range (fig. 7). From the northwest part of the domain through the Amargosa River drainage and into Death Valley, the futureclimate simulated recharge was less than or equal to present-day simulated recharge. The low-lying areas near the Spotted Range also had future-climate simulated recharge rates that were less than or equal to present-day simulated conditions.

The distribution of recharge was similar for the past-climate and future-climate simulations, but the rate was generally higher for the past-climate conditions (fig. 8). Because the same method was used to determine recharge for the past-climate and futureclimate conditions, areas of high and low recharge were generally similar. The variations were caused by differences between the simulated climate. A much larger portion of the model domain had zero recharge in the future-climate simulation (fig. 4). The simulated past recharge was 1 to $25 \mathrm{~mm} / \mathrm{yr}$ greater than the simulated future recharge over most of the model domain (fig. 8). The Spring Mountains received the most recharge in both the past- and future-climate conditions (figs. 3 and 4), and this area received over $250 \mathrm{~mm} / \mathrm{yr}$ more recharge in the past-climate simulations than in the future-climate simulations (fig. 8).

\section{DESCRIPTION OF GROUND-WATER- FLOW MODEL}

The Death Valley regional ground-water-flow model used for this study was developed as part of the U.S. Geological Survey Yucca Mountain Project site characterization program. The present-day model has been documented by D'Agnese and others (1997). The numerical code used in this study is MODFLOWP (Hill, 1992). MODFLOWP is an adaptation of the U.S. Geological Survey three-dimensional, finite-difference modular ground-water-flow model, MODFLOW (McDonald and Harbaugh, 1988; Hill, 1992) in which nonlinear regression is used to estimate model parameters that result in the best fit to measured hydraulic heads and ground-water discharge rates. MODFLOWP is a block-centered finite-difference code that simulates a three-dimensional flow system as a sequence of porous-media layers.

\section{Simplifying Assumptions}

The ground-water-flow model has four major simplifying assumptions:

(1) Ground water in the Death Valley region flows through fractured volcanic and carbonate rocks, as well as porous valley-fill alluvium. However, discrete-fracture flow simulation is impractical at a regional scale, and, therefore, all flow is assumed to occur through porous media. Zones of high or low hydraulic conductivity are used to account for highly faulted and fractured regions. This assumption probably produces reasonable approximations to regionalscale flow patterns.

(2) Hydraulic conductivity within each model cell is assumed to be homogeneous and horizontally isotropic. Thus, hydraulic conductivity variations smaller than the grid cells are not represented. This assumption probably produces reasonable approximations to regional-scale flow patterns, but local-scale flow patterns probably are not adequately represented.

(3) The system can be assumed to be virtually at steady state. Four conditions may cause this assumption to be violated. First, the regional flow system still may be undergoing a drying-out sequence following a wetter climate cycle related to the late Pleistocene. Second, ground-water withdrawals by wells for domestic, municipal, mining, and irrigation uses have imposed recent stresses on the present-day system. This pumpage is derived initially from ground-water storage. The steady-state model, however, omits the possibility of deriving water from storage, so that water flowing to wells must be offset by capture of natural discharge. The future-climate simulation assumes that future pumpage remains at present-day rates; the past-climate simulation assumes no pumpage. Third, the flow system may experience seasonal or annual fluctuations that are not simulated. Longer-term average conditions are simulated. Fourth, water levels, spring flows, and other data used in model calibration were collected over an interval of many years, and these data may contain seasonal and 


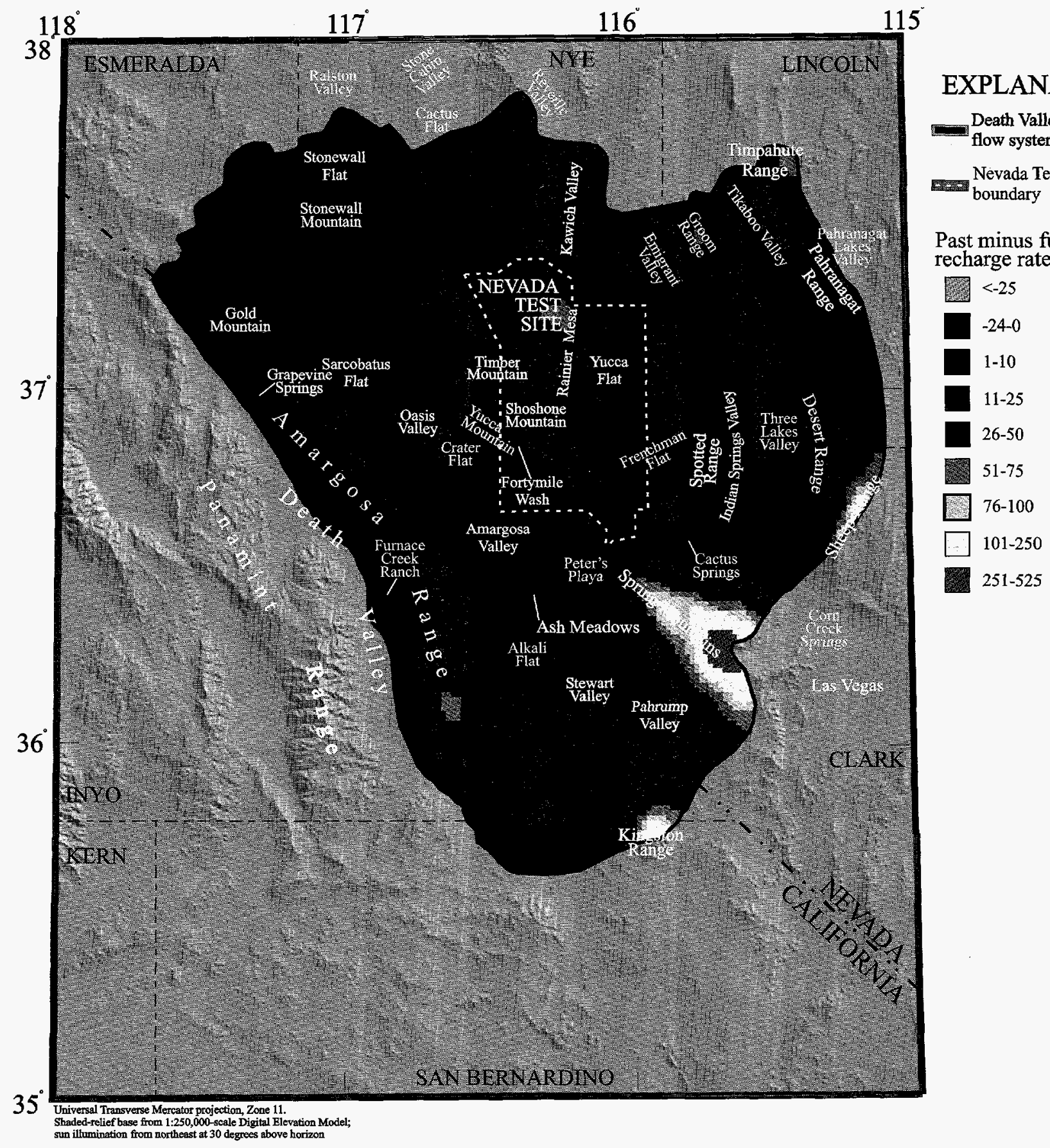

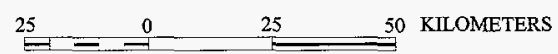

$25 \stackrel{0}{=} \quad-\quad 25 \quad 50$ MILES

Figure 8. Difference between past-climate and future-climate simulated recharge distributions. 
annual variations to the ground-water-flow system, and may not reflect steady-state, average-annual, groundwater conditions.

(4) In the Death Valley regional flow model, saturated thickness in model layers is constant. Although the top layer in the natural flow system is unconfined in most areas, defining its present-day thickness from a potentiometric-surface map and representing the layer as confined produces a close approximation and is much more efficient numerically. During periods of increased recharge conditions, however, the uppermost layer will likely have a higher saturated thickness in many locations. This cannot occur in the model because of the current configuration.

This is an important limitation because a change in saturated thickness has a direct effect on transmissivity. If changes in water levels are small, then saturated thickness and transmissivity will likely not change significantly. If changes in water levels are large, however, then water-level rises resulting from these climate-change simulations may be overestimated.

Modification of the model to simulate these types of unconfined conditions is beyond the scope of this study. As a result, the simulations should be considered approximations of the effects of climate change on the flow system.

\section{Model Grid}

The model contained 163 rows, 153 columns, and 3 layers, for a total of 74,817 cells. The model grid was oriented north-south. Cell spacing along both rows and columns was $1,500 \mathrm{~m}$. The three model layers represented aquifer properties at $0-500 \mathrm{~m}, 500$ $1,250 \mathrm{~m}$, and $1,250-2,750 \mathrm{~m}$ below an interpolated and smoothed potentiometric surface; layers were 500 , 750 , and 1,500 $\mathrm{m}$ thick, respectively. The first and second model layers generally simulated local and subregional flow mostly within valley-fill alluvium, volcanic rocks and shallow carbonate rocks. The third layer generally simulated regional flow in the volcanic, carbonate, and clastic rocks (D'Agnese and others, 1997).

\section{Present-Day Model Parameters and Boundaries}

The model used as the starting point in the current analysis is documented in detail by D'Agnese and others (1997). In general, the regional model boundaries extend to mountain ranges that generally consist of low-permeability consolidated rock. The external boundaries were assumed to be no-flow boundaries except in some areas in the north and northeast where constant-head boundaries were used to simulate potential ground-water underflow. A constant-head boundary was used at the Death Valley saltpan to simulate evaporation of water out of the system (D'Agnese and others, 1997).

Hydraulic conductivities throughout the model domain were divided into nine different zones and values for hydraulic conductivity ranged from $1 \times 10^{-6} \mathrm{~m} /$ day to about $20 \mathrm{~m} /$ day. Recharge was simulated as an areally distributed input to cells in the upper layer that generally correspond to mountain ranges. Recharge rates were defined as a percentage of present-day, average annual precipitation. Four recharge zones were used with values ranging from 0 percent of average annual precipitation in the valley bottoms to 23 percent of average annual precipitation on the tops of the highest mountains. Discharge occurred primarily as evapotranspiration, spring flow, and pumpage. Evapotranspiration was simulated as a head-dependent function with the rate dependent on depth to water below land surface. Regional springs were simulated as head-dependent flux boundaries and were assigned to the lower layers of the model, which represented more regional flow. Pumpage was assigned to cells where estimated ground-water withdrawal occurred.

\section{CLIMATE-CHANGE SIMULATIONS}

The past- and future-climate simulations relied heavily on the present-day Death Valley flow-system model developed by D'Agnese and others (1997). The model domain and discretization was identical. Furthermore, model parameters and boundaries used in the present-day model, except recharge and pumpage, generally were not changed for the past- or futureclimate simulations. Where model boundaries were changed, the changes are noted in subsequent sections. The hydrogeologic framework was assumed not to have changed or to change during these simulations. 


\section{Past-Climate (Full-Glacial) Simulations}

Past-climate simulations required the following changes to the present-day ground-water-flow model:

(1) modification of boundary conditions;

(2) modification of recharge distribution;

(3) conversion of evapotranspiration areas into wetlands; and (4) elimination of pumpage. Because few data were available to describe the hydrologic conditions under full glaciation, the simulation required numerous simplifying assumptions.

\section{Boundary Conditions}

The boundary conditions for past-climate simulations were modified from those used in the presentday flow model (D'Agnese and others, 1997).

Constant-head cells were used to simulate paleolakes (fig. 2) that were present $21 \mathrm{ka}$, the largest of which was Lake Manley in Death Valley. The constant heads in the lake areas were assigned values equal to interpreted paleoshoreline altitudes. The four major paleolakes simulated were Kawich Valley, Cactus Flats, Emigrant Valley, and Death Valley.

The location of constant-head boundaries along the northern and northeastern edge of the model were the same as those used in the present-day model, but constant heads were assigned to all three model layers (fig. 9) whereas only layer 3 was assigned a constant head in the present-day model. Assigning constant heads to all three layers allowed the potentially larger underflow of ground water that may have occurred in the past into the model domain. Constant heads assigned to these model cells were designated to represent levels for paleolakes that existed just outside the model domain in Ralston, Stone Cabin, and Reveille Valleys (fig. 9). A constant-head boundary set equal to land-surface altitude also was used in all layers on the northeastern edge of the model domain, near the Pahranagat Range, to represent ground-water flux to or from the Pahranagat Lakes area (fig. 9). In the presentday model, this area had constant-head cells only in layer 3 .

\section{Recharge}

Climatic conditions $21 \mathrm{ka}$ were significantly wetter than present; average annual precipitation distributions for this period were developed by Thompson and others (National Center for Atmospheric Research, written commun., February 1996). These simulated increases in average annual precipitation resulted in higher ground-water recharge rates than those that exist in the present-day region.

Regional ground-water recharge rates developed for the past-climate simulation (J.A. Hevesi and A.L. Flint, U.S. Geological Survey, written commun., June, 1997) were resampled to a 1,500-m model grid (fig. 3). The estimated recharge rates in several areas of the model domain exceeded the model hydraulic conductivity of layer 1 , so water would be added to the system at a greater rate than the hydrogeologic units could transmit. This would have occurred in several mountain ranges with low hydraulic-conductivity units. Under natural conditions, surface runoff would occur when recharge exceeded hydraulic conductivity. The surface runoff may evaporate, may be consumed by vegetation, may infiltrate back into the groundwater system at some lower altitude, or may form ponds or wetlands.

To simulate rejected recharge, drains (McDonald and Harbaugh, 1988) were added to mountain-top areas of the model that were coincident with areas where recharge exceeded hydraulic conductivity. The drains were simulated as being at land-surface altitudes.

\section{Conversion of Evapotranspiration Areas to Wetlands (Drains)}

The present-day flow model included a headdependent function to simulate evapotranspiration areas; however, in the past-climate simulations, potential wetland areas were simulated as head-dependent boundaries, or drains (McDonald and Harbaugh, 1988). The location and extent of potential wetlands under wetter climatic conditions was constrained to mapped paleodischarge deposits (fig. 9). Drains also were assigned to model cells that represent present-day wetlands. Ground water was discharged to these drains only where simulated past water levels rose above the land surface. Paleodischarge areas were simulated in Sarcobatus Flat, Oasis Valley, and several areas in the Amargosa Valley including Peter's Playa, Ash Meadows, and Alkali Flat. Additional ground-water discharge areas were located near Stonewall Mountain, Indian Springs Valley, Stewart Valley, and Pahrump Valley (fig. 9).

Drains also were simulated along major tributary surface-water drainages, including the Amargosa River and Fortymile Wash (fig. 9). The drains along these surface-water features were used to simulate gainingstream conditions. 

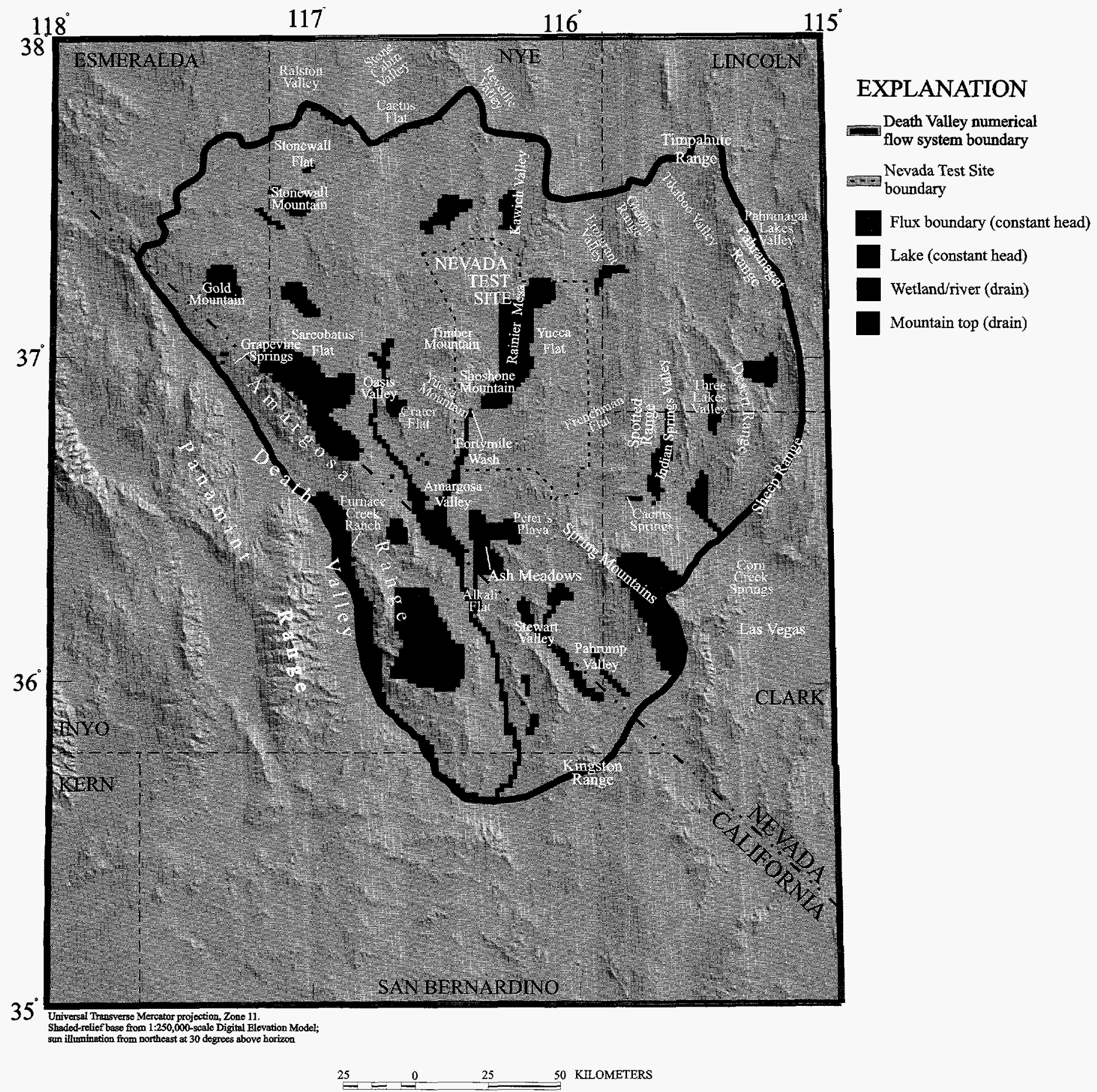

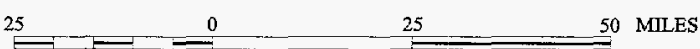

Figure 9. Distribution of paleodischarge areas that were represented as constant head cells and drains in the past-climate conditions ground-water flow model simulation. 
The conductance (McDonald and Harbaugh, 1988) assigned to these drains was estimated to be similar to those used in the present-day ground-waterflow model. Drains used to simulate Grapevine Springs and Oasis Valley were assigned a conductance of $10 \mathrm{~m}^{2} /$ day, which is approximately the conductance used for these features in the present-day model. The conductance of all other drains was set to $100 \mathrm{~m}^{2} /$ day, which was the value used in the present-day model for large volume springs at Ash Meadows and in Death Valley at Furnace Creek Ranch.

\section{Pumpage}

The present day ground-water-flow model (D'Agnese and others, 1997) assigned pumpage to cells where estimated ground-water withdrawal occurred. Pumpage in the model was eliminated for past-climate conditions $21 \mathrm{ka}$.

\section{Future-Climate (Global-Warming) Simulations}

Future-climate simulations required the following changes to the present-day ground-waterflow model: (1) modification of boundary conditions;

(2) modification of recharge distribution; and

(3) conversion of evapotranspiration areas into wetlands. Because few data were available to describe the hydrology of the model area under future conditions, the simulation required numerous simplifying assumptions.

\section{Boundary Conditions}

The boundary conditions for future-climate simulations were modified from those used in the present-day model (D'Agnese and others, 1997). The location of constant-head boundaries along the northern and northeastern edge of the model domain were the same as those used in the present-day model except that constant-head cells were assigned to all three layers. Assigning constant heads to all three layers allowed the potentially larger underflow of ground water that may occur in the future into the model domain. Constant heads assigned to these model cells were designated to represent future watertable elevations in the northern and northeastern model boundaries in Ralston Valley, Stone Cabin Valley, Reveille Valley, and the Pahranagat Lakes area (fig. 10). For the future-climate simulation the constant-head cell elevations were set equal to land surface.

The location, extent, and elevation of lakes and wetlands under the simulated future climate conditions was unknown. Therefore, constant-head cells were not used to represent those surface-water features; instead, head-dependent nodes were used to simulate possible lakes and wetlands.

\section{Recharge}

The simulated future-climate conditions were wetter in most parts of the model domain than the present conditions (fig. 7). The increase in average annual precipitation rates resulted in higher than present-day infiltration rates and, likewise, was simulated as an increase in recharge to the ground-waterflow system.

Regional ground-water recharge rates developed for the future-climate simulation (A.L. Flint and J.A. Hevesi, U.S. Geological Survey, written commun., 1996) were resampled to a 1,500-m model grid (fig. 4). As in the past-climate condition, recharge rates in several areas of the model domain exceeded the model hydraulic conductivity of layer 1 . As was done for past-climate simulations, drains (McDonald and Harbaugh, 1988) were added to mountain-top areas of the model that were coincident with areas where recharge exceeded hydraulic conductivity.

\section{Conversion of Evapotranspiration Areas to Wetlands (Drains)}

Potential lakes and wetlands were simulated as head-dependent boundaries, or drains, in the futureclimate simulations. The extent of lakes and marshes under wetter climatic conditions was constrained by maps that describe paleoshorelines and isolated paleodischarge deposits. Regional ground water will likely discharge in these areas as it did in the past. Drains were assigned to model cells where present-day wetlands exist and where evidence for paleolakes and marshes exist (fig. 10). Ground water will discharge from these drains only where simulated future water levels rise above the land surface.

For past-climate simulations, the Death Valley saltpan was simulated as constant-head cells set to a paleolake level for Lake Manley. In the future-climate simulation, however, these cells were assigned as drains. Ground water is expected to discharge from the 


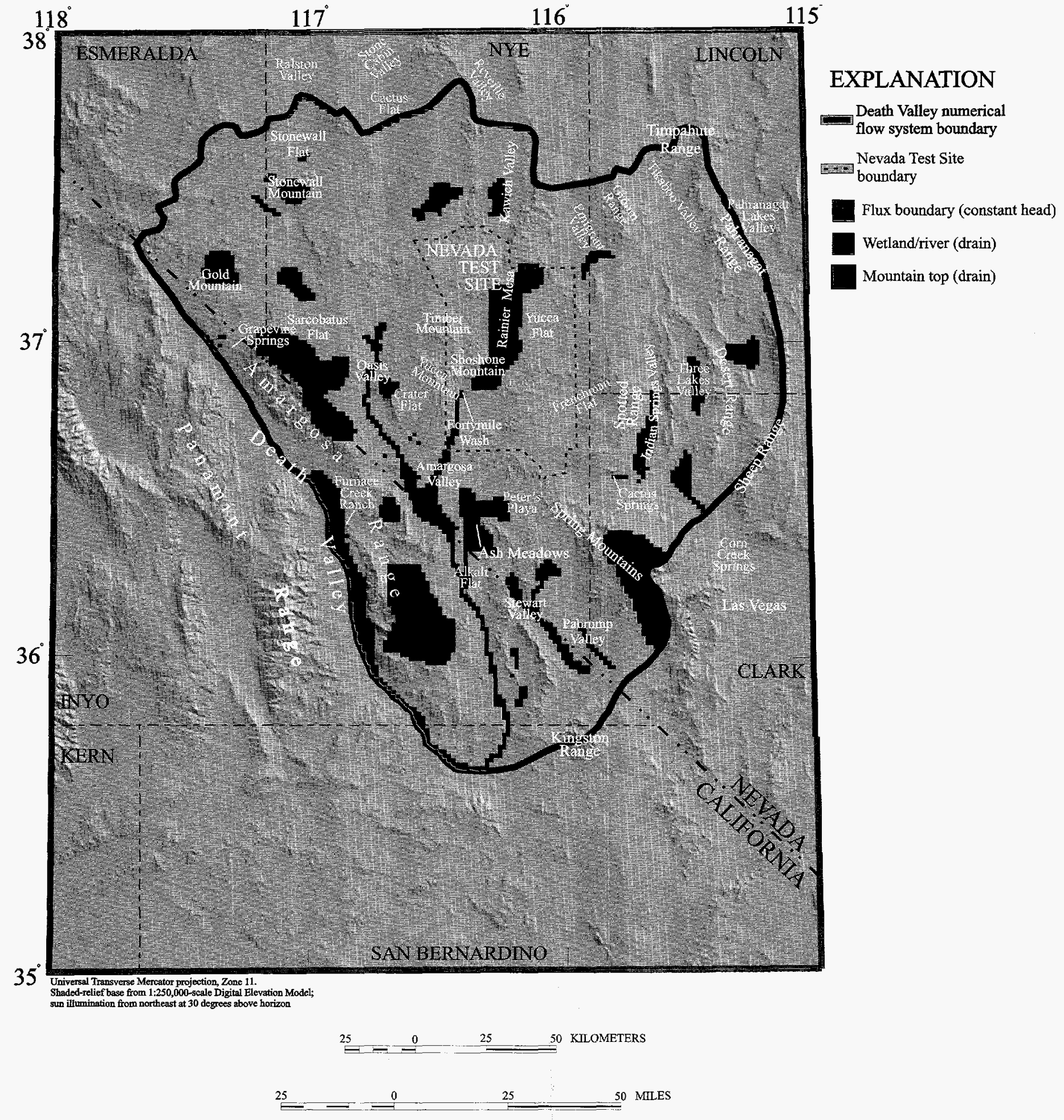

Figure 10. Distribution of constant head cells and potential discharge areas that were represented as drains in the future-climate conditions ground-water flow model simulation. 
saltpan in the future, but it is unknown whether a lake would form. Therefore, drains were used to simulate the ground-surface elevation where discharge would occur.

As in past-climate simulations, drains were located along tributary surface-water drainages that are predicted to flow under wetter than present-day climate conditions. These surface-water tributaries include the Amargosa River and Fortymile Wash (fig. 10). Likewise, drains were added to mountain-top areas coincident with high recharge and low hydraulic conductivity units to account for rejected recharge (fig. 10).

\section{Pumpage}

Well discharge was simulated to remain at the present-day levels used in the regional ground-water steady-state model (D'Agnese and others, 1997). Therefore, no changes were made to well parameters for future-climate simulations.

\section{SIMULATED EFFECTS OF CLIMATE CHANGE}

The simulated effects of climate change were evaluated by observing simulated discharge areas, water-level changes, potentiometric-surface configurations, and water budgets. The past- and future-climate simulations produced results that generally were similar to those produced by the present-day Death Valley flow-system model (D'Agnese and others, 1997). The following sections emphasize where the models differed.

\section{Past-Climate (Full-Glacial) Simulations}

The past-climate simulation contained much more recharge than the present-day simulation. To allow the past-climate simulation to produce a potentiometric-surface configuration consistent with known discharge areas, the conductance of discharge-area drains was adjusted. The past-climate model simulated a potentiometric surface that was generally similar, but higher than that simulated with the present-day model. The past-climate model simulated numerous wetlands and lakes and had substantially more water flowing through it than the present-day model.

\section{Evaluation of Drain Conductance}

The model simulations indicated that water levels in the low-lying areas were highly sensitive to drain conductance. High-conductance drains allowed water that rose to the drain altitude to be discharged without restriction. As a result, water levels did not rise above land surface in the areas that surround the drains. Low-conductance drains restricted the flow of water out of the discharge area. If the flow of water toward the drains was greater than the rate at which it could be discharged with the given conductance, water levels rose. Overestimating the drain conductance resulted in artificially suppressed water levels in the low-lying areas of the Amargosa Valley and southern Amargosa River drainage.

Drain conductance for the Grapevine Springs and Oasis Valley areas was set to $10 \mathrm{~m}^{2} /$ day, which was the approximate value used in the present-day model ( 11 and $1.7 \mathrm{~m}^{2} /$ day respectively). Conductances of all other drains located in the model domain were set to $100 \mathrm{~m}^{2} /$ day for the past-climate simulation, which was the value used for the Ash Meadows springs in the present-day model.

During calibration, various conductance values were simulated. When the conductance of all drains was set to $10 \mathrm{~m}^{2} / \mathrm{day}$, higher water levels occurred throughout the model domain. Drain conductance equal to $10 \mathrm{~m}^{2} /$ day resulted in water levels rising up to $200 \mathrm{~m}$ more in the low-lying areas and 100 to $200 \mathrm{~m}$ in the higher areas when compared to simulations with drain conductance equal to $100 \mathrm{~m}^{2} /$ day. With drain conductance equal to $10 \mathrm{~m}^{2} /$ day, water levels at Yucca Mountain increased about $200 \mathrm{~m}$ relative to the present-day model. This water-level rise also resulted in unacceptably large discharge rates at many of the specified paleodischarge sites. Therefore, conductance values of $10 \mathrm{~m}^{2} /$ day at Grapevine Springs and Oasis Valley and $100 \mathrm{~m}^{2} /$ day elsewhere resulted in a potentiometric-surface configuration and discharge rates that were consistent with paleohydrologic interpretations.

Higher water levels near the discharge areas resulted in a decreased hydraulic gradient away from the higher recharge areas, which caused water levels upgradient from the discharge areas to also rise. Water levels in the Timber Mountain area, for example, were 100 to $200 \mathrm{~m}$ higher in the $10-\mathrm{m}^{2} /$ day conductance condition than in the $100-\mathrm{m}^{2} /$ day conductance condition. Conversely, if drain conductance was set unreasonably high $\left(10,000 \mathrm{~m}^{2} /\right.$ day $)$, water levels in the lowlying areas were below the water levels simulated 
under present-day conditions. The combination of drain conductance values of $10 \mathrm{~m}^{2} /$ day for the Grapevine Spring and Oasis Valley drains and $100 \mathrm{~m}^{2} /$ day for the other drains provided flux out of the model at expected paleodischarge sites and most nearly approximated the potentiometric-surface configuration calculated for the present-day flow model. Because recharge was the only input parameter that was changed for the past-climate simulation, it was expected that the potentiometric surface would have a configuration similar to the one simulated in the present-day model.

\section{Discharge Areas}

Discharge from the flow system under simulated past-climate conditions occurred as flow to constanthead cells or drains. Under past-climate conditions, ground water was simulated as flowing out of the model domain toward the Pahranagat Lakes area on the northeastern model boundary (fig. 11). Under present-day conditions, ground water was simulated as flowing into the model domain through these constant head cells. High rates of paleorecharge in the Pahranagat, Sheep, and Desert Ranges (fig. 3) formed a simulated ground-water divide along the southern Pahranagat Range, which isolated this area from the Death Valley regional ground-water-flow system. Therefore, recharge near the northeastern model boundary was simulated as flowing toward the east and out of the model domain, and recharge on the west side of the ground-water divide was flowing toward the Frenchman Flat area.

The lakes in the north-central part of the model domain were predominately discharging water under the simulated past-climate conditions (fig. 11). As a result of the increased recharge, water levels rose in the northern part of the model and resulted in discharge to the simulated lake areas. The lake in Emigrant Valley has cells with water entering the flow system as well as cells with water exiting the flow system. On the upgradient side of the lake, ground water entered the lake and maintained this feature. A smaller volume of water moved out of the downgradient side of the Emigrant Valley lake (Groom Lake), indicating that a surface-water component may enter the ground-water system at this point.

The largest surface-water feature in the model domain is Lake Manley (fig. 2). All constant-head cells that represent Lake Manley were simulated as discharging water to the lake under the past-climate conditions (fig. 11). As in the present-day system, Death Valley (Lake Manley) is the major discharge point in the regional ground-water-flow system with large volumes of water flowing toward this area.

Most of the drains in low-lying areas had water discharging from the model because simulated water levels rose above land surface (fig. 11). Discharging drains were simulated in the Sarcobatus Flat and Oasis Valley areas, and south through the Amargosa Valley. Peter's Playa, Ash Meadows, and Alkali Flat were simulated as major discharge areas under the pastclimate conditions. The simulation indicated that surface-water drainages along the Amargosa River and southern part of Fortymile Wash were gaining streams. The simulated drains in Stewart Valley, Pahrump Valley, and Corn Creek Springs were discharging ground water that had entered the flow system in the Spring Mountains as recharge.

A few areas with simulated drains were predicted not to have discharge under the simulated past-climate conditions (fig. 11). Drains in the Indian Springs Valley discharged only in the area closest to the Spring Mountains near present-day Indian and Cactus Springs (fig. 11). Drains in the Three Lakes Valley also did not discharge water under the simulated past-climate conditions.

Potential discharge areas closest to Yucca Mountain were located in Fortymile Wash and the southern end of Crater Flat (fig. 11). The drains located in the northern portion of Fortymile Wash, to the east of Yucca Mountain, did not discharge water under the past-climate simulations. Although ground water was not simulated as discharging in the northern part of Fortymile Wash, the potentiometric-surface contours indicated that ground water was flowing toward the Fortymile Wash area. Water was discharging from drains in the southern portion of Fortymile Wash where it flowed into the Amargosa River. Drains at the southern end of Crater Flat also were not simulated as discharging. The potentiometric surface, however, did appear to have been close to the land surface in this area. The proximity of the potentiometric surface to the land surface in southern Crater Flat could support a phreatophyte community.

In general, the past-climate simulation appears to replicate the predicted paleodischarge areas reasonably well. Based only on discharge areas, the simulation, therefore, is considered to be a valid representation of interpreted paleoclimatic and paleohydrologic conditions at approximately $21 \mathrm{ka}$. 


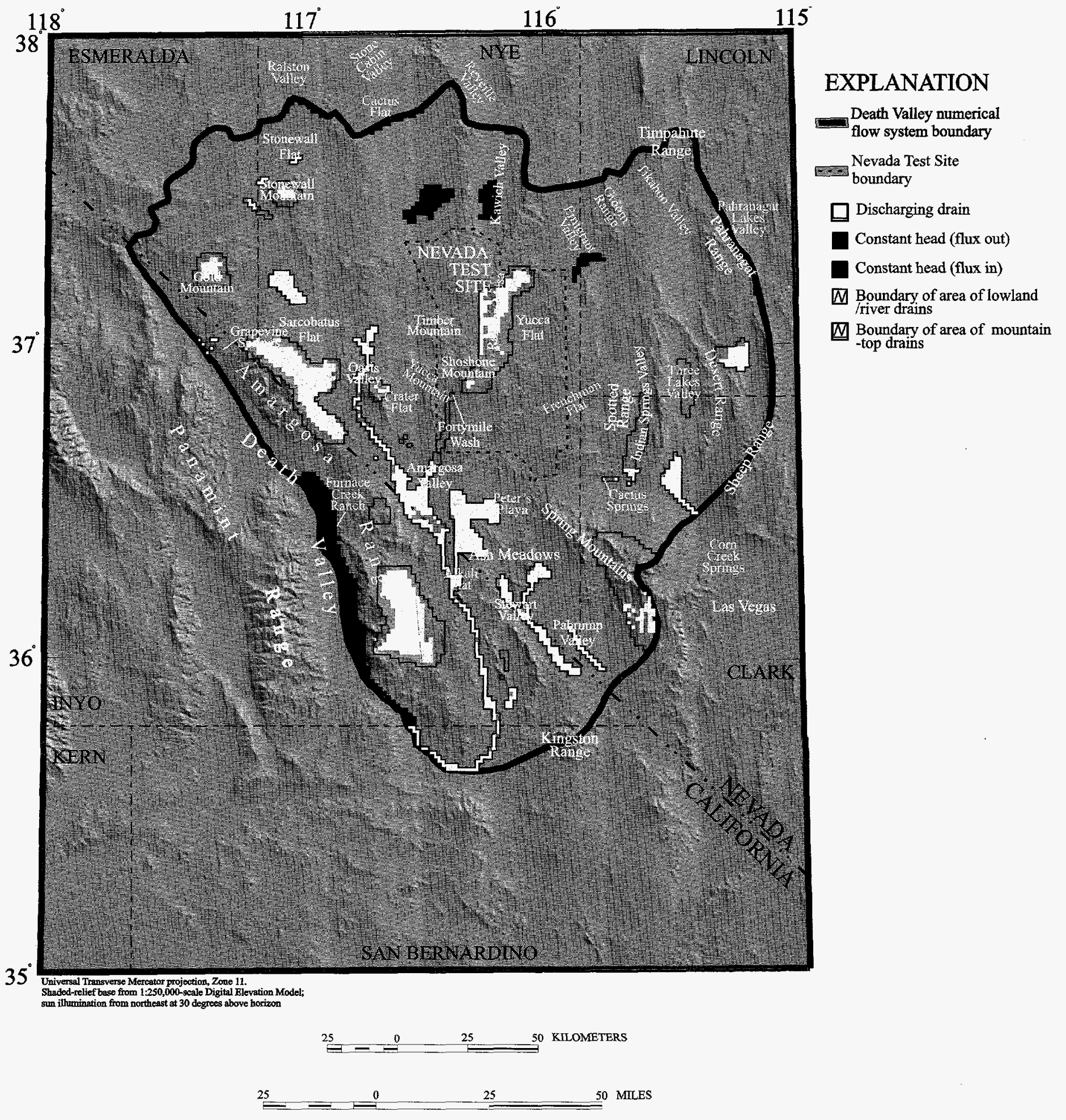

Figure 11. Distribution of drains and constant head cells that were simulated as discharging during past-climate conditions. 


\section{Mountain-Top Drains}

Most mountain-top drains, used in areas of high simulated recharge and low hydraulic-conductivity hydrogeologic units, discharged water from the model under past-climate conditions (fig. 11). Water levels were generally simulated as being at land surface in the Amargosa Range, Stonewall Mountain, and Gold Mountain. Rainier Mesa also had a majority of the drains simulated as discharging water. The high recharge rates that resulted in discharge through the drains could indicate locally perched water, rejected recharge becoming surface-water runoff, locally discharging springs, or increased evapotranspiration from upland wetlands.

Mountain-top drains in the Shoshone Mountain area, to the north and east of Yucca Mountain, were not simulated as discharging water under the pastclimate condition (fig. 11). Water levels in these areas did not rise substantially as a result of the increased recharge rates. In general, the Spring Mountains were simulated as having from 25 to over $250 \mathrm{~mm} / \mathrm{yr}$ more recharge under past-climate conditions than under the present-climate conditions (fig. 6). These high recharge rates, however, resulted in simulated water levels rising above land surface and discharging through drains only in a few locations in the Spring Mountains area (fig. 11). The scarcity of discharging mountain-top drains was most likely a result of the very high hydraulic-conductivity units in this area.

\section{Potentiometric-Surface Configuration}

The potentiometric surface simulated using the wetter, past-climate conditions was compared to the potentiometric surface simulated using present-day climate conditions (D'Agnese and others, 1997) (fig. 12). The past-climate potentiometric surface was generally similar to the present-day simulated surface, but differences do exist (fig. 13).

\section{Regional Potentiometric Surface}

Water levels generally rose over the entire model domain as a result of the increased recharge rates. Higher altitude areas generally received the largest increase in recharge, and hence, water levels rose most dramatically in model layer 1 in these areas (fig. 13). Large hydraulic gradients that existed in the present-day model became more pronounced, but remained in the same location under the past-climate conditions. Even though there was an overall increase in recharge, some areas had lower recharge for the past-climate condition than was simulated for the present-day condition. This relative decrease in recharge resulted in simulated water-level declines in some areas.

Water levels across the northern part of the model generally rose at least $100 \mathrm{~m}$ (fig 13) as a result of up to $100 \mathrm{~mm} / \mathrm{yr}$ more recharge in these areas (fig. 6). In the north-central part of the model domain, increased recharge resulted in a more pronounced potentiometric-surface mound near Rainier Mesa (fig. 13). The large hydraulic gradient between Rainier Mesa and Yucca Flat was even more pronounced than under present-day conditions because of the increase in water levels on Rainier Mesa.

The north-south-trending Amargosa Range received up to $75 \mathrm{~mm} / \mathrm{yr}$ more recharge in the simulated past-climate conditions than in the present-day model (fig. 6). The higher recharge rates coupled with generally low hydraulic-conductivity units resulted in water levels rising over $100 \mathrm{~m}$ (fig. 13) and reaching the land surface in some areas. Some of the infiltrating water was discharged through mountain-top drains in these areas (fig. 11). Most of the recharge appears to have flowed toward the Amargosa Valley and Lake Manley, where it was removed from the flow system.

The increase in recharge, and resulting rise in water levels, was most dramatic in the Spring Mountains where recharge rates in the past-climate simulations were over $250 \mathrm{~mm} / \mathrm{yr}$ higher in some areas than in the present-day model (fig. 6). Water levels rose from 100 to over $1,000 \mathrm{~m}$ in the Spring Mountains, resulting in a much larger hydraulic gradient in this area (fig. 13). Some of the water from the Spring Mountains flowed toward the Las Vegas area where it discharged at wetlands near present-day Corn Creek Springs (fig. 11). The spring and marsh areas simulated as drains in the Pahrump Valley also were discharging water flowing from the Spring Mountains.

The simulated potentiometric surface indicated that ground-water flow was focused toward the simulated lowland discharge areas (fig. 13). From Oasis Valley to the southern part of the Amargosa River drainage, ground water was flowing toward drains creating a V-shaped potentiometric surface along the Amargosa River. 


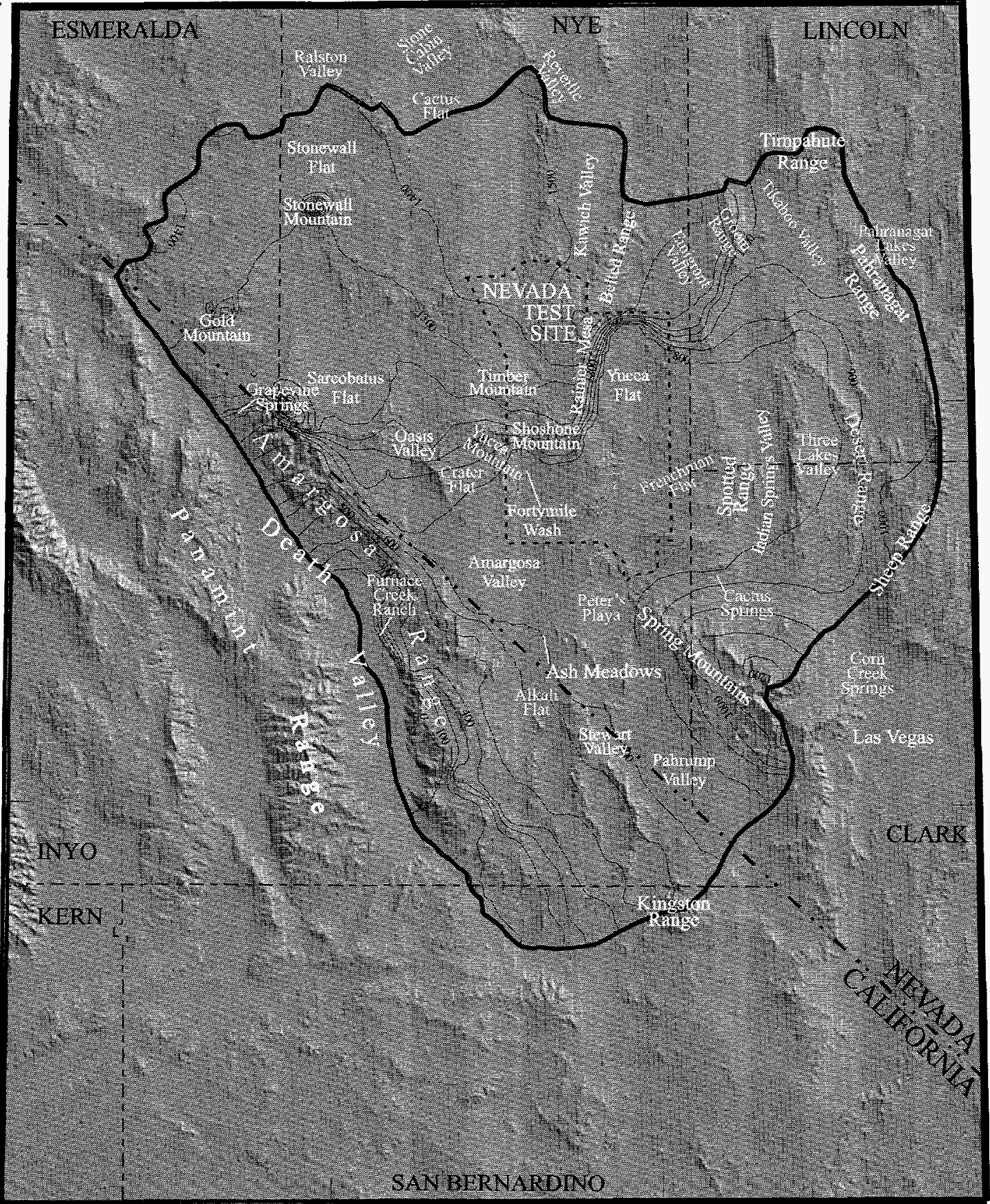

$35^{\circ}$

Universal Transverse Mercator projection, Zone 11.

Shaded-relief base from 1:250,000-scale Digital Blevation Model
sun illumination from northeast at 30 degrees above horizon

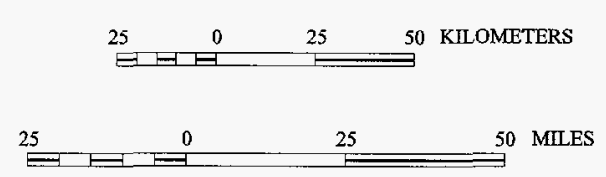

Figure 12. Simulated present-day climate potentiometric surface for model layer 1 (D'Agnese and others, 1997). 


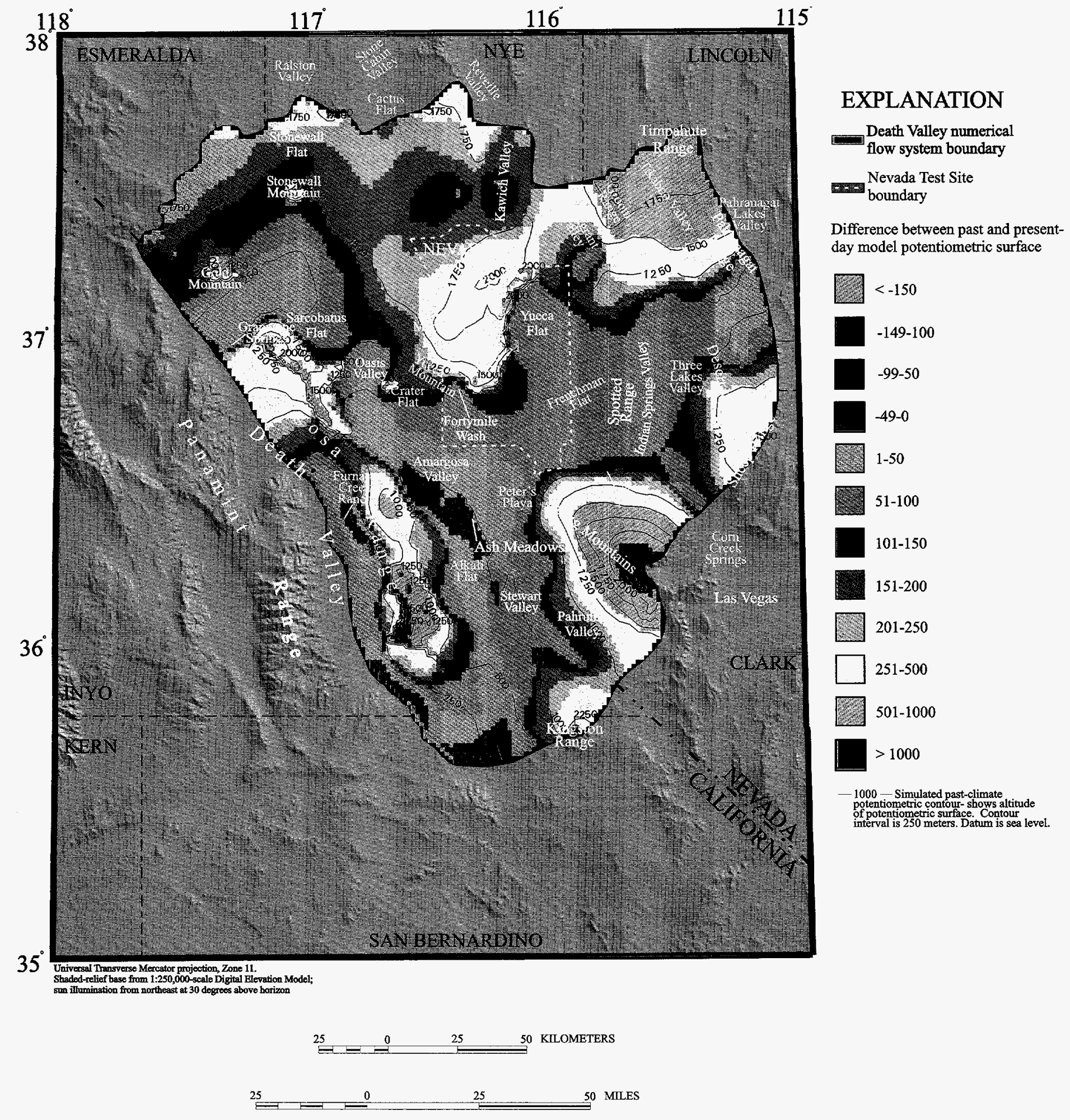

Figure 13. Simulated past-climate conditions potentiometric-surface for model layer 1 and the difference between the past and present-day model layer 1 potentiometric surface. 
In the Sarcobatus Flat area, water levels rose up to $100 \mathrm{~m}$, whereas water levels in the surrounding upland areas rose more than $100 \mathrm{~m}$ (fig. 13). A pronounced ground-water basin formed in the Sarcobatus Flat area, and a well-defined ground-water divide formed between Sarcobatus Flat and Oasis Valley to the southeast. Water that flowed into the Sarcobatus Flat area continued to flow toward the western model boundary where some water discharged at Grapevine Springs and some water continued south to discharge at Lake Manley (fig. 13).

Moderate water-level increases, up to $100 \mathrm{~m}$, were simulated in the low-lying areas of the model under the past-climate conditions. The relatively small-gradient area in the central part of the model domain did not change substantially under the simulated wetter climate conditions (fig. 13). The waterlevel rises in this area were most likely limited because of the relatively high hydraulic conductivity of this region and the increased discharge to Ash Meadows. If the discharge areas had not been as efficient at removing water from the flow system, water levels in the low-lying areas would probably rise.

The potentiometric surface simulated for model layer 3 in the past-climate simulation is illustrated in figure 14. The simulated potentiometric surface in layer 3 was generally higher than simulated presentday levels (fig. 15) throughout the model domain. The generally higher recharge rates in the past-climate simulations affect the lower part of the regional flow system. The potentiometric surface rose up to $100 \mathrm{~m}$ in the low-lying areas and up to $250 \mathrm{~m}$ in most of the higher altitude areas. In the high-recharge areas, including the Spring Mountains, Timpahute Range, Sheep Range, and Timber Mountain area, simulated potentiometric-surface increases were over $250 \mathrm{~m}$. The potentiometric-surface for model layer 3 is important because it describes deep regional ground-water flow.

Recharge rates in the past-climate condition were lower in some areas than the rates simulated for the present-day condition. This resulted in water-level declines in these areas relative to the simulated present-day potentiometric surface. Areas with simulated water-level declines in model layer 3 included the southernmost part of the modeled area and parts of Amargosa Valley and Death Valley (fig. 14).

\section{Yucca Mountain Potentiometric Surface}

Changes in the potentiometric surface near Yucca Mountain are of particular interest because of the potential effects water-level changes could have on the potential repository. Simulated water levels near Yucca Mountain in the past-climate condition for model layer 1 were generally between 60 and $150 \mathrm{~m}$ higher than present-day levels (fig. 13). These simulated increases in water levels beneath Yucca Mountain are comparable with estimates developed by Czarnecki (1985, p. 21) that indicated a maximum rise of about $130 \mathrm{~m}$ with an assumed 100 percent increase in precipitation. These water levels were still below the potential repository horizon, which is located between 200 and $400 \mathrm{~m}$ above the present-day water table.

The most substantial water-level increases in the Yucca Mountain area occurred to the north and northeast in the Timber and Shoshone Mountain areas. Water levels rose in the Timber Mountain area (fig. 13) because recharge was generally 25 to $50 \mathrm{~mm} / \mathrm{yr}$ higher than under present-day conditions (fig. 6). Water level increases in these areas were $500 \mathrm{~m}$ or less.

The highest water levels in the present-day potentiometric surface occur in the Belted Range (fig. 12). Past-climate simulations indicate that this high water-level area would expand to the southwest, toward Timber Mountain (fig. 13). These higher water levels to the north of Yucca Mountain increase the areal extent of the present-day large hydraulic gradient. The increased water levels in the pastclimate simulations caused the large hydraulic gradient to the north of Yucca Mountain to become more pronounced. However, the large hydraulic gradient at Yucca Mountain appears to be stationary, and it does not migrate south toward the potential repository block.

Water-level rises to the east, west, and south of Yucca Mountain, including Fortymile Wash, Frenchman Flat, Crater Flat, and Amargosa Valley, were generally less than $150 \mathrm{~m}$. The shape of the potentiometric surface in these areas did not change substantially from the present-day conditions (figs. 12, 13).

Near Yucca Mountain, the simulated pastclimate condition potentiometric surface in layer 3 was about $100 \mathrm{~m}$ higher than in the present-day simulation (fig. 14). An increase in water levels in model layer 3 suggests that the dominantly upward gradient 


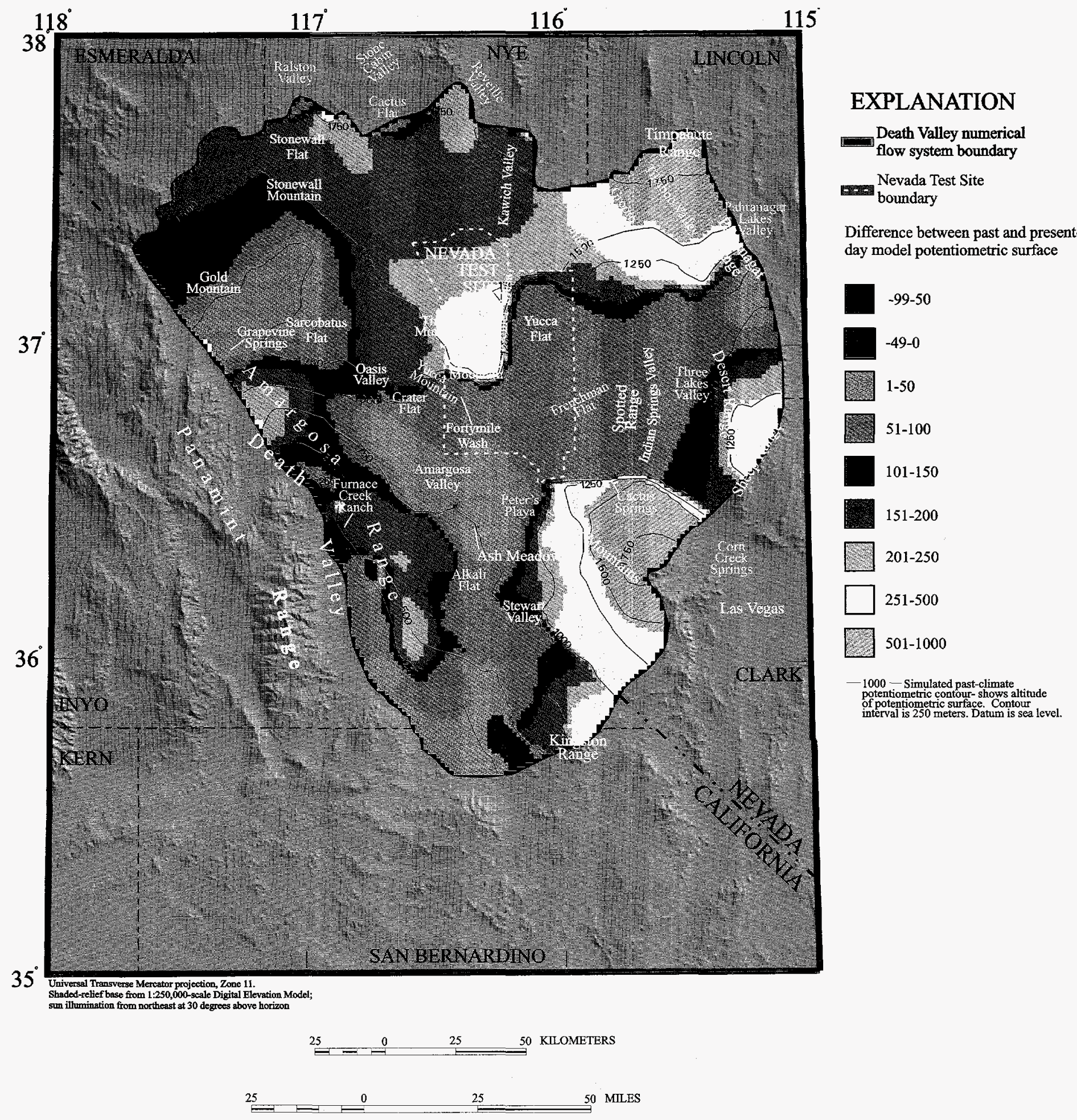

Figure 14. Simulated past-climate conditions potentiometric surface for model layer 3 and the difference between the past and present-day model layer 3 potentiometric surface. 

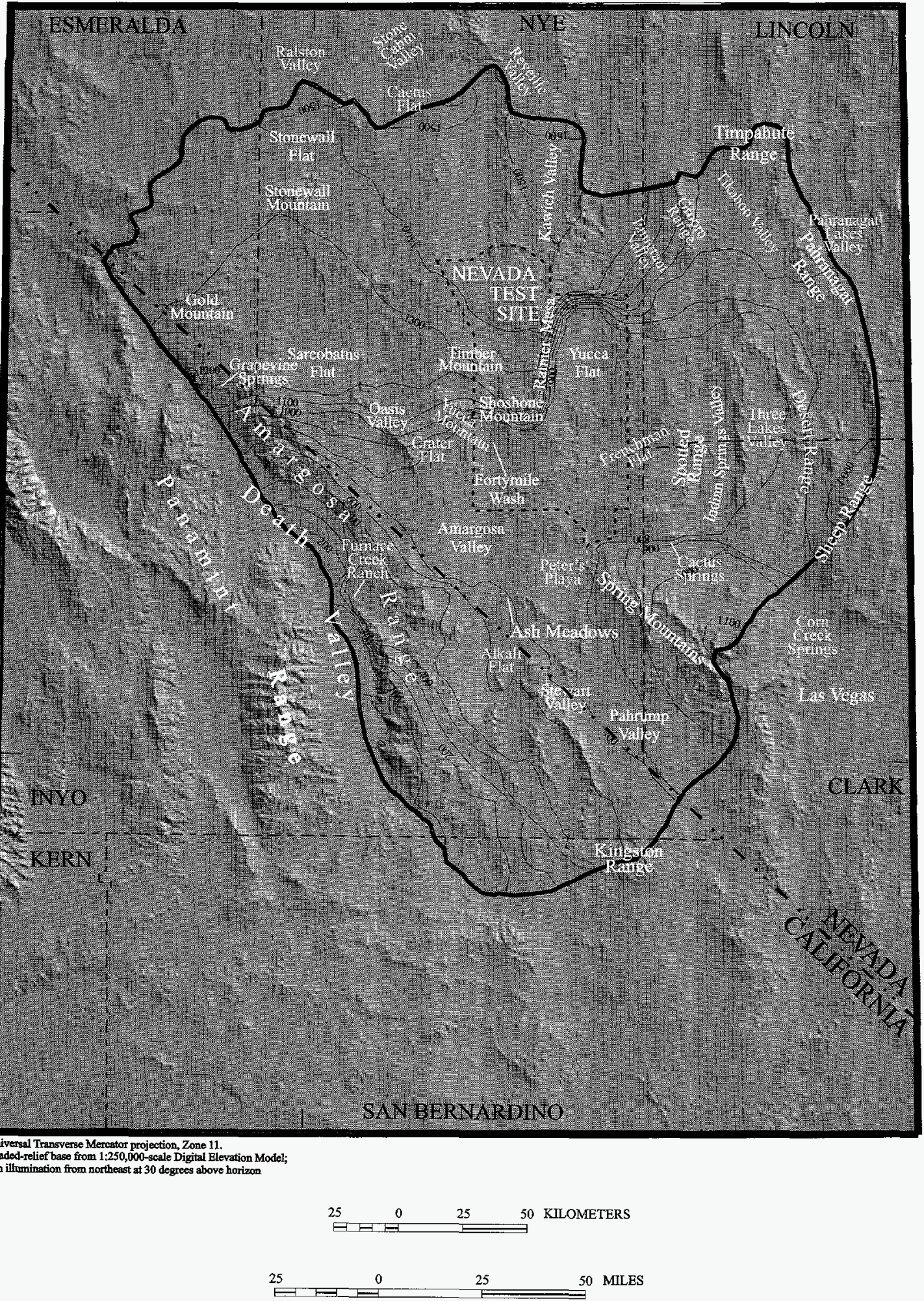

Figure 15. Simulated present-day potentiometric surface for model layer 3 (D'Agnese and others, 1997). 
under the potential repository would be maintained under wetter climatic conditions. The past-climate potentiometric surface in layer 3 has the same general configuration throughout the model domain as the present-day surface (figs. 14,15). Layer 3 water levels in areas with high recharge, such as Timber and Shoshone Mountains however, have the most substantial increases (fig. 14).

The potentiometric surface downgradient from Yucca Mountain was basically the same in the pastclimate and present-day simulations, so flow paths are expected to remain the same. Ground water will predominately flow south toward the discharge areas in the Amargosa Valley. Particle-tracking simulations necessary to provide more detailed information and to further define the flow paths from Yucca Mountain were beyond the scope of this report.

\section{Water Budget}

The water budget provides information about water that entered or exited the model through specified cells (table 1). The past-climate simulation budget indicated that the model was close to being in balance. The discrepancy between inflows and outflows was 0.11 percent, which indicates an apparent, slightly larger rate of water exiting the system than entering. Numerical errors associated with the convergence of the model solution probably were the source of the small budget discrepancy. Given the small discrepancy, the numerical solution obtained in the simulation was adequate.

Recharge accounted for nearly 97 percent of the water that entered the modeled area. The total recharge under the simulated past-climate conditions was 6.3 times higher than the recharge simulated in the present-day model (table 1). Underflow entered the model through constant-head cells on the northern boundary and as recharge. Most of the water that entered the model through constant-head cells entered through Ralston Valley and Kawich Valley (table 1).

Water exited the model through drains in recharge (mountain-top drains) and discharge (lowland drains) areas and through constant-head cells at simulated lakes. Most of the water, 72 percent of the total flux out, exited the flow system through discharge area drains most of which are located in the Amargosa Valley. The simulated lakes in Cactus Flat, Kawich Valley, and Emigrant Valley discharged 57 percent of the water leaving the model through constant-head cells. Lake Manley and the Pahranagat Lakes area account for 24 percent and 19 percent of water, respectively, that exited the model through constant-head cells.

Mountain-top drains discharged about 7 percent of the total flow that attempted to enter the system. Most of the simulated recharge was able to enter the flow system and was not converted directly to surfacewater flow. The 7 percent recharge that was removed from the flow system through mountain-top drains should be considered rejected recharge because it did not have an opportunity to enter the flow system. Instead, this water was probably discharged close to the recharge area as cold temperature springs, surfacewater runoff, or evapotranspiration. In table 1, rejected recharge was subtracted from total recharge to obtain net recharge; only net recharge actually entered the regional flow system.

\section{Future-Climate (Global-Warming) Simulations}

The future-climate simulation contained slightly more recharge overall than the present-day simulation. The simulated potentiometric surface under these conditions was generally similar, but higher than that simulated with the present-day model (fig. 12). Because the overall recharge was less than that simulated for the past-climate simulation, fewer drain cells were discharging water at both mountain-top areas and lowland areas.

\section{Discharge Areas}

Under simulated future-climate conditions, ground water flows into the model domain from the Pahranagat Lakes area located on the northeastern model boundary (fig. 16). Because of the decreased gradient in this part of the model domain resulting from increased recharge, the influx through these constant-head cells is less than the influx simulated in the present-day steady-state model.

About one-half of the drains in the Cactus Flat, Kawich Valley, and Emigrant Valley areas discharged water under the future-climate conditions (fig. 16). The major lowland discharge areas in the futureclimate simulations were Sarcobatus Flat, Oasis Valley, Peter's Playa, and Ash Meadows (fig. 16). The number of discharging drains in the Amargosa River drainage progressively increased to the south. Most of the drains in the Death Valley area discharged water. 
Table 1. Net flux into and out of the model used to simulate past-climate conditions (modified from D'Agnese and others, 1997, p. 112, table 17)

\begin{tabular}{|c|c|c|c|c|}
\hline & & & $\begin{array}{c}\text { Past-climate } \\
\text { simulations } \\
\text { Net flux, in cubic } \\
\text { meters per day }\end{array}$ & $\begin{array}{l}\text { Present-climate } \\
\text { simulations } \\
\text { Net flux, in cubic } \\
\text { meters per day }\end{array}$ \\
\hline \multicolumn{5}{|l|}{ FLUX IN: } \\
\hline & CONSTANT HEADS: & Ralston Valley underflow & 34,000 & \\
\hline & & Stone Cabin Valley underflow & 6,000 & \\
\hline & & Kawich Valley underflow & 26,000 & \\
\hline & & NET CONSTANT HEADS & 66,000 & $1_{83,000}$ \\
\hline & RECHARGE: & Total recharge & $1,951,000$ & \\
\hline & & Rejected recharge & $-136,000$ & \\
\hline & & NET RECHARGE & $1,815,000$ & 290,000 \\
\hline & TOTAL FLUX IN: & & $1,881,000$ & 373,000 \\
\hline \multicolumn{5}{|l|}{ FLUX OUT: } \\
\hline & CONSTANT HEADS: & Death Valley (Lake Manley) & 103,000 & 74,000 \\
\hline & & $\begin{array}{l}\text { Pahranagat Lakes } \\
\text { underflow }\end{array}$ & 79,000 & 0 \\
\hline & & Other lakes & $\underline{243.000}$ & 0 \\
\hline & & NET CONSTANT HEADS & 425,000 & 74,000 \\
\hline & WELLS & & 0 & $\begin{array}{r}88,000 \\
\end{array}$ \\
\hline & DRAINS & Wetland discharge areas & $1,458,000$ & ${ }^{2} 212,000$ \\
\hline & TOTAL FLUX OUT: & & $1,883,000$ & 374,000 \\
\hline \multicolumn{3}{|c|}{ FLUX IN MINUS FLUX OUT } & $-2,000$ & $-1,000$ \\
\hline \multicolumn{3}{|c|}{ PERCENT DISCREPANCY ${ }^{3}$} & -0.11 & -0.3 \\
\hline
\end{tabular}

${ }^{1}$ Constant-heads flux includes ground water entering through Pahranagat Lakes area.

${ }^{2}$ In present-day simulation, discharge simulated using evapotranspiration and drain packages.

${ }^{3}$ Percent discrepancy reflects primarily numerical errors associated with convergence of the model solution. 


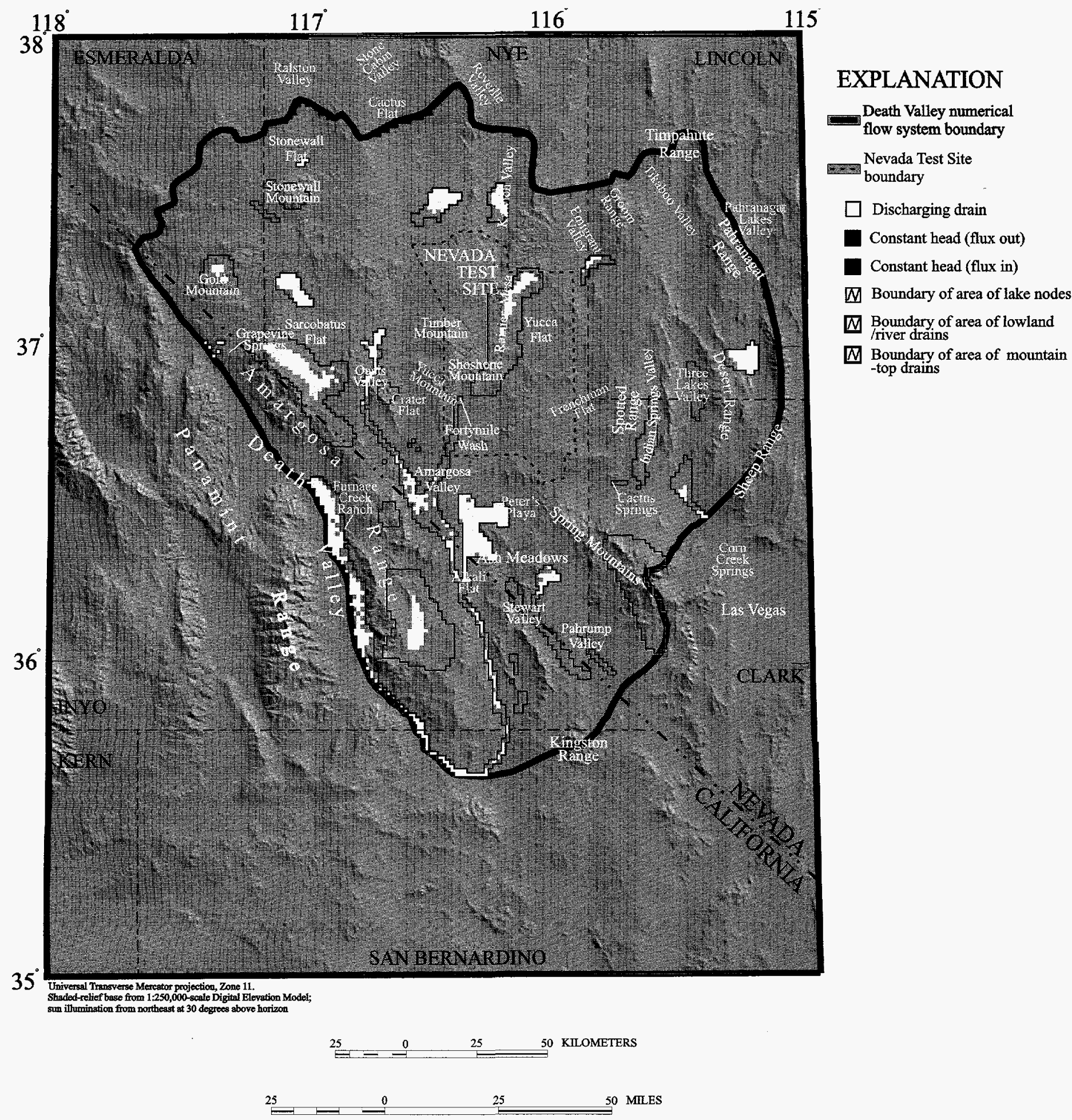

Figure 16. Distribution of constant head cells and drains that were simulated as discharging during future-climate conditions. 
The future-climate simulation did not increase water levels to land surface in several of the areas simulated as drains (fig. 16). For example, most of the drains in Three Lakes Valley, Corn Creek Springs, Las Vegas Valley, Indian Springs Valley, Pahrump Valley, and Stewart Valley did not discharge water.

\section{Mountain-Top Drains}

Mountain-top drains on Gold Mountain, the Amargosa Range, and Rainier Mesa discharged water under the simulated future-climate conditions (fig. 16). The Spring Mountains did not have any discharging drains, indicating that the recharge in this area was not high enough to cause water levels to rise above the land surface. Likewise, mountain-top drains in Shoshone Mountain did not discharge water under the simulated future-climate conditions (fig. 16).

\section{Potentiometric-Surface Configuration}

Water-level increases greater than $100 \mathrm{~m}$ in layer 1 were common in the northern and northeastern areas of the model domain under the future-climate conditions (fig. 17). Recharge rates up to $75 \mathrm{~mm} / \mathrm{yr}$ higher in the northeast portion of the model domain (fig. 7) resulted in water-level increases of up to $500 \mathrm{~m}$. Areas of high recharge in the Spring Mountains and Amargosa Range had water-level increases greater than $100 \mathrm{~m}$. The future-climate simulation resulted in a smaller area of the model domain with water-level increases greater than $100 \mathrm{~m}$ compared to the past-climate simulations.

\section{Regional Potentiometric Surface}

The potentiometric surface rose less than $100 \mathrm{~m}$ in most areas of the model domain under the simulated future-climate conditions (fig. 17). Sarcobatus Flat had virtually no change in water levels compared to the present-day conditions. The potentiometric surface in the lowland areas to the north and east of Sarcobatus Flat rose less than $100 \mathrm{~m}$. Oasis Valley, Pahrump Valley, and the Spotted Range area had water-level increases that were generally less than $100 \mathrm{~m}$.

Parts of the Amargosa Valley, Amargosa River drainage, and Death Valley had simulated water levels that were equal to or lower than present-day conditions (fig. 17). There are several possible reasons for the relatively minor increases and declines in the potentiometric surface throughout parts of the model domain under the simulated future-climate conditions. The source of water to these areas was less in the future-climate simulations than in the present-day model simulations. Simulated water-level declines in Death Valley and the southern portions of the Amargosa River were probably attributable to reduced recharge in these areas. The areas of only moderate water-level changes were generally coincident with areas of reduced recharge. While the simulated climatic conditions were generally wetter in the future, there were areas where recharge was less than simulated in the present-day model (fig. 7). Water levels did not rise significantly in the areas around drains unless the flux of water toward the drains exceeded the capacity of the drain. The combination of less recharge and adequate drain capacity resulted in moderate increases or decreases in the potentiometric surface. Under natural conditions it is unlikely that all of the lowland drain areas would discharge water.

There were no major differences between the shapes of the simulated present-day and future-climate potentiometric surfaces, so flow directions were also similar (figs. 12, 17). Minor differences in the potentiometric surfaces result from differences in the distribution of recharge.

The potentiometric surface in model layer $3 \mathrm{had}$ generally moderate increases in the future-climate simulations relative to the present-day potentiometric surface (figs. 18, 15). The northern part of the model domain generally had water-level increases up to $150 \mathrm{~m}$, except in the Timpahute Range area where increases were more than $250 \mathrm{~m}$. The largest waterlevel increases in layer 3 are generally coincident with areas of highest simulated recharge. Lower elevation areas within the model domain generally had waterlevel increases of $50 \mathrm{~m}$ or less.

\section{Yucca Mountain Potentiometric Surface}

Water levels simulated at Yucca Mountain rose less than $50 \mathrm{~m}$ in the future-climate condition (fig. 17). These water levels were still well below the potential repository, which is located between 200 and $400 \mathrm{~m}$ above the present-day water table. The Crater Flat and Fortymile Wash areas also had water-level increases of $50 \mathrm{~m}$ or less, which was common for the lower elevation portions of the model domain. The largest waterlevel increases in the Yucca Mountain area were to the 


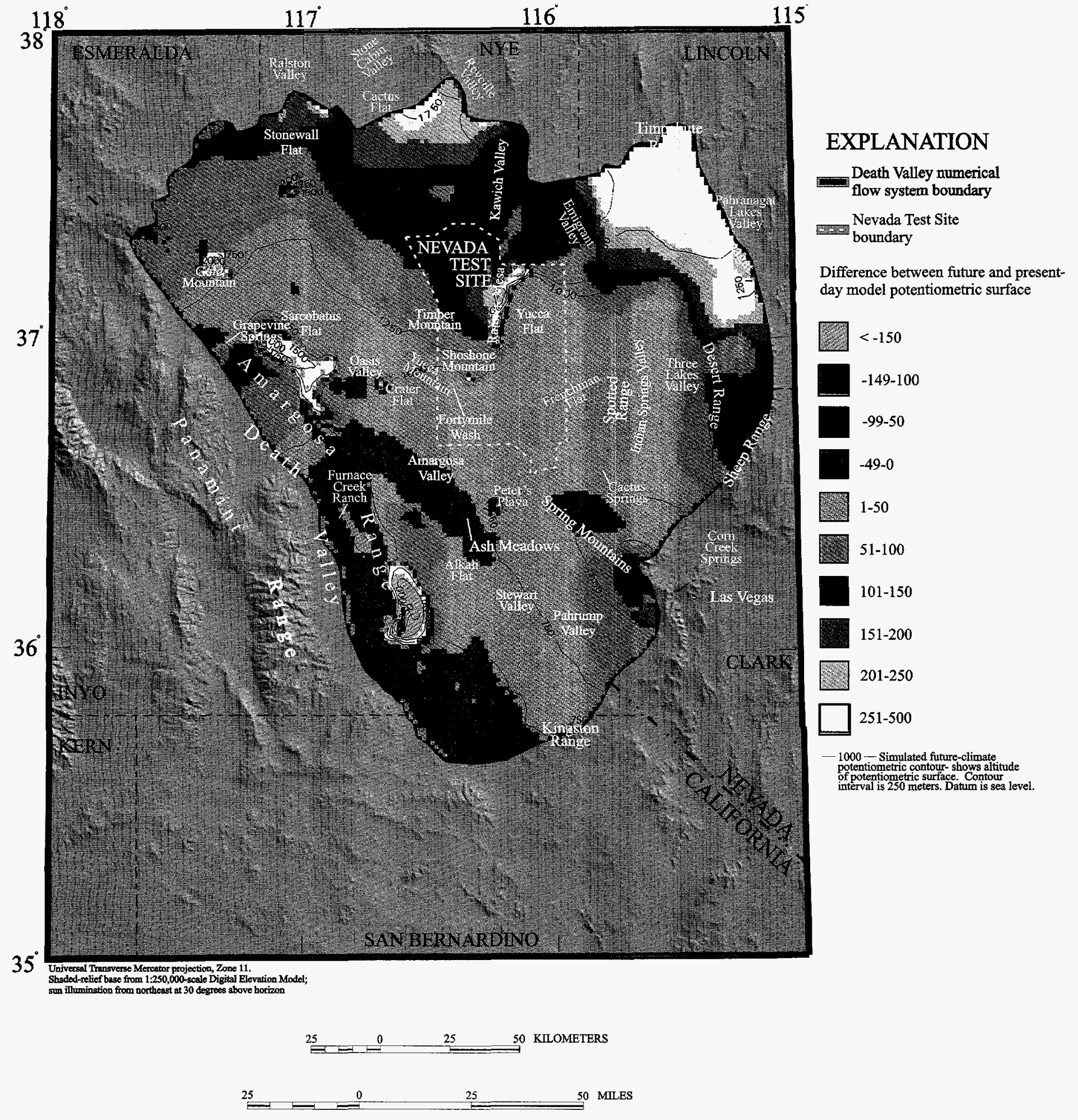

Figure 17. Simulated future-climate conditions potentiometric surface for model layer 1 and the difference between the future and present-day model layer 1 potentiometric surface. 


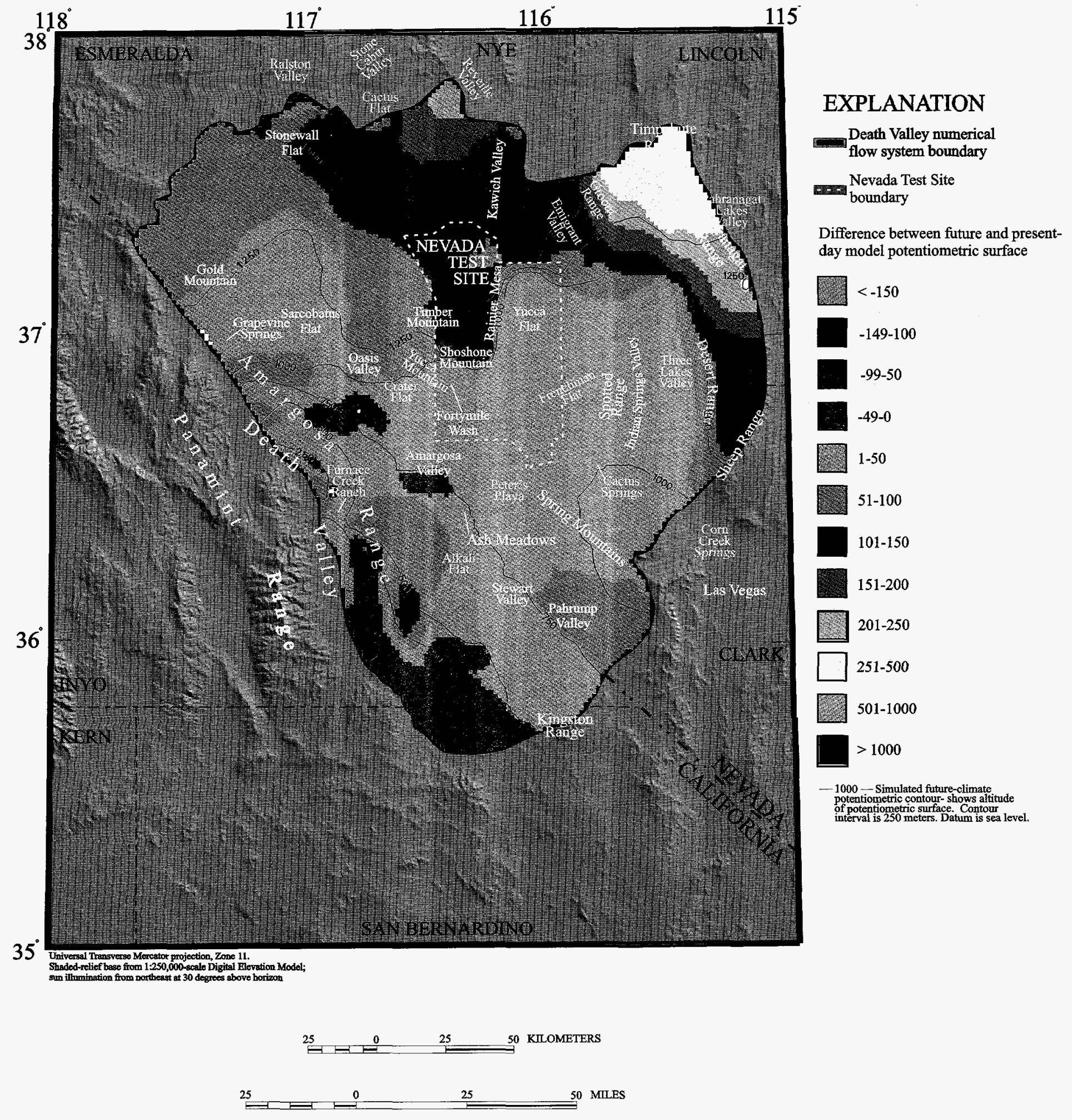

Figure 18. Simulated future-climate conditions potentiometric surface for model layer 3 and the difference between the future and present-day model layer 3 potentiometric surface. 
north and northeast in the Timber and Shoshone Mountain areas. Water levels in these areas generally rose $100 \mathrm{~m}$ or less. Simulated water levels on Rainier Mesa were over $100 \mathrm{~m}$ higher than present-day conditions, which resulted in a more pronounced hydraulic gradient toward Yucca Flat.

The potentiometric-surface configuration of layer 1 near Yucca Mountain in the future-climate condition was very similar to the present-day simulations (fig. 12). The large hydraulic gradient to the north of Yucca Mountain retained the shape and location simulated in the present-day conditions, and water levels rose less than $100 \mathrm{~m}$. The large hydraulic gradient does not migrate south toward the potential repository block in the future-climate simulation.

The potentiometric surface in layer 3 near Yucca Mountain had water-level increases of about $50 \mathrm{~m}$ relative to the present-day potentiometric surface (figs. 15, 18). Layer 3 water-level increases were less than $50 \mathrm{~m}$ in the Crater Flat, Fortymile Wash, and Amargosa Valley areas that surround Yucca Mountain (fig. 18). The present-day upward gradient in layer 3 is maintained and enhanced in the future-climate simulation.

Flow paths from Yucca Mountain in the futureclimate conditions are expected to remain the same as present-day conditions because the configuration of the potentiometric surface in model layer 1 is largely unchanged (figs. 12, 17). Ground water will predominately flow south toward the discharge areas in the Amargosa Valley. Particle-tracking simulations necessary to provide more detailed information and to define flow paths farther from Yucca Mountain were beyond the scope of this report.

\section{Water Budget}

The future-climate simulations water budget indicated that the model was close to being in balance (table 2). The discrepancy between inflows and outflows is -1.5 percent, which indicates an apparent, slightly larger rate of water that exits the system than enters. Given the small discrepancy, the numerical solution obtained in the simulation was adequate.

Most of the water, 74 percent of net inflow, entered the model as recharge. The total recharge under the simulated future-climate conditions was 1.8 times higher than the recharge simulated in the present-day model. Flow through constant-head cells in Ralston Valley, Stone Cabin Valley, Kawich Valley, and Pahranagat Lakes accounted for 26 percent of the inflow.

Water exited the model as drain and well discharge (table 2). The lowland discharge areas that were simulated as drains discharged 87 percent of the water leaving the model. Less than 1 percent of the flux that exited the model was through the mountaintop drains. Since 1.1 percent of the recharge was discharged through the mountain-top drains (rejected recharge), most of the simulated total recharge entered the flow system as net recharge. Well discharge accounted for the remaining 12 percent of flux out of the model.

\section{LIMITATIONS OF CLIMATE-CHANGE SIMULATIONS}

Numerical modeling has substantial limitations when used to evaluate the effects of climate change on the regional ground-water-flow system of the Death Valley region. To emphasize the conceptual nature of these climate-change evaluations, the limitations of this study are listed below.

(1) The predictive simulations can be no more accurate than the present-day, steady-state regional ground-water-flow model (D'Agnese and others, 1997) on which they were based. The limitations in the accuracy of that model were described in detail in D'Agnese and others (1997).

(2) The past-climate simulation was evaluated for reasonableness by comparing it to the known distributions of paleodischarge areas. Paleohydrologic evidence is critical to the validity of the simulations, and this evidence of past-discharge areas is incomplete. Many paleodischarge sites may not have been preserved, and numerous locations of discharge may not have been included as potential areas of groundwater flux out of the model. Additionally, some of the paleodischarge areas that were described as potential regional ground-water discharge points may be points of local, rather than regional, ground-water discharge. Also, discharge rates from these paleodischarge sites were unknown and thus cannot be used as a reasonableness check.

(3) The average annual precipitation distributions for past- and future-climate conditions are output from global-scale climate models used by Thompson 
Table 2. Net flux into and out of the model used to simulate future-climate conditions (modified from $D^{\prime}$ Agnese and others, 1997, p. 112, table 17)

\begin{tabular}{|c|c|c|c|c|}
\hline & & & $\begin{array}{l}\text { Future-climate } \\
\text { simulations } \\
\text { Net flux, in cubic } \\
\text { meters per day }\end{array}$ & $\begin{array}{l}\text { Present-climate } \\
\text { simulations } \\
\text { Net flux, in cubic } \\
\text { meters per day }\end{array}$ \\
\hline \multicolumn{5}{|l|}{ FLUX IN: } \\
\hline & \multirow[t]{5}{*}{ CONSTANT HEADS: } & Ralston Valley underflow & 23,000 & \\
\hline & & Stone Cabin Valley underflow & 38,000 & \\
\hline & & Kawich Valley underflow & 25,000 & \\
\hline & & $\begin{array}{l}\text { Pahranagat Lakes } \\
\text { underflow }\end{array}$ & 98,000 & \\
\hline & & NET CONSTANT HEADS & 184,000 & ${ }^{1} 83,000$ \\
\hline & \multirow[t]{4}{*}{ RECHARGE: } & Total recharge & 524,000 & \\
\hline & & Rejected recharge & & \\
\hline & & NET RECHARGE & $-6,000$ & \\
\hline & & & 518,000 & 290,000 \\
\hline & \multicolumn{2}{|l|}{ TOTAL FLUX IN: } & 702,000 & 373,000 \\
\hline \multirow[t]{4}{*}{ FLUX OUT: } & \multicolumn{2}{|l|}{ CONSTANT HEADS } & 0 & 74,000 \\
\hline & \multicolumn{2}{|l|}{ WELLS } & 88,000 & 88,000 \\
\hline & \multicolumn{2}{|l|}{ DRAINS } & 625,000 & 2212,000 \\
\hline & \multicolumn{2}{|l|}{ TOTAL FLUX OUT: } & 713,000 & 374,000 \\
\hline \multicolumn{3}{|c|}{ FLUX IN MINUS FLUX OUT } & $-11,000$ & $-4,000$ \\
\hline & \multicolumn{2}{|c|}{ PERCENT DISCREPANCY 3} & -1.5 & -0.3 \\
\hline
\end{tabular}

${ }^{1}$ Constant-heads flux includes ground water entering through Pahranagat Lakes area.

${ }^{2}$ In present-day simulation, discharge simulated using evapotranspiration and drain packages.

${ }^{3}$ Percent discrepancy reflects primarily numerical errors associated with convergence of the model solution. 
and others (National Center for Atmospheric Research, written commun., February 1996, August 1996). These precipitation distributions were calculated from a 50-

$\mathrm{km}$-grid model. Resampling this data to the $1.5-\mathrm{km}$ grid required for the regional ground-water-flow model reduces the accuracy of the data because the assumptions of climate-scale models are not valid at $1.5-\mathrm{km}$ spacing.

(4) The recharge estimates for past- and futureclimate conditions were developed from the average annual precipitation maps that had been resampled to a $1.5-\mathrm{km}$ grid. The recharge distributions, which were the input for climate-change simulations, were developed by using a modification of the Maxey-Eakin method (Maxey and Eakin, 1949). This method is based on using altitude ranges that approximate zones of recharge under present-day moisture conditions. Under different climate conditions, the mechanisms that control recharge likely would change because the moisture properties of the landscape would also likely change, and the Maxey-Eakin method may no longer be appropriate.

(5) In these simulations, surface-water features, including lakes and rivers, were supported only by ground-water discharge, and surface-water runoff was not simulated. Under natural conditions, these features would have at least some surface-water component. Because the rivers were simulated as drains, they could not lose water to the ground-water-flow system. The Amargosa River and Fortymile Wash may have both gaining and losing reaches during different climate conditions.

(6) Flux out of past or future discharge areas is unknown. Therefore, the validity of a simulation could only be qualitatively judged by evaluating if discharge was occurring in likely locations.

(7) Flux out of specified discharge areas was sensitive to simulated drain conductance. The conductance values for the drains specified in the past and future simulations were somewhat similar to those used in the present-day model; however, the appropriate values for conductance in each of these drains was difficult to estimate. Because of model sensitivity to this parameter, the validity of model results was uncertain.

(8) The boundary conditions for the present-day model were not completely known, and boundary conditions are likely to change under different climatic conditions. Exactly how these boundaries will change in response to climate change is unknown and a limitation to the regional climate-change simulations.

(9) The past- and future-climate simulations did not use evapotranspiration as a means of removing ground water from the model. Drains were used to achieve a similar effect. However, drains will remove ground water from the model only when simulated water levels rise above land surface. Evapotranspiration will remove ground water from the model even if simulated water levels do not rise above land surface. Therefore, the model may be underestimating the amount of water that would be removed from the system in discharge areas.

(10) For the future-climate simulation, groundwater pumping was assumed to remain constant from present conditions. Ground-water use likely would increase in the future. The amount of ground-water use expected in the future, however, is not known.

(11) Both past- and future-climate simulations assume that the regional ground-water-flow system would rapidly reach a steady-state condition following climate changes. Given the size of the ground-waterflow system, this assumption may not be valid.

\section{SUMMARY AND CONCLUSIONS}

In cooperation with the U.S. Department of Energy, the U.S. Geological Survey is evaluating the geologic and hydrologic characteristics of the Death Valley regional ground-water-flow system as part of the Yucca Mountain Project. Because radionuclides potentially could be transported by ground water from the repository to the accessible environment, ground-waterflow system dynamics are being characterized. The evaluation of the Yucca Mountain site includes a detailed characterization of the ground-water-flow system. As part of the detailed characterization, a regional three-dimensional numerical ground-waterflow model was developed. By using this ground-waterflow model, the potential effects of full-glacial and global-warming climates were evaluated.

The study area is located along the border of southwestern Nevada and southeastern California. The area is immediately west of the city of Las Vegas, Nevada, and includes parts of Esmeralda, Nye, Lincoln, and Clark Counties in Nevada, and Inyo and San Bernardino Counties in California.

To assess the effects of climate change, two simulations were made. First, as a reasonableness check on 
future-climate conditions, a simulation that was based on past climatic conditions was evaluated by comparing the results of the simulation to observations of paleodischarge sites. By using climatic conditions that were postulated to have existed 21,000 years ago under full-glacial conditions, the ground-water-flow system was simulated. Second, a possible future ground-water-flow system that represents globalwarming conditions was simulated. Climate changes were simulated with the regional ground-water-flow model by changing the distribution of ground-water recharge.

Average annual precipitation maps both for past and future climate conditions were developed by previous investigators and resampled to the model grid resolution. A polynomial function that represents the Maxey-Eakin area-altitude relation was then used to develop recharge distributions from precipitation that was suitable for simulation.

Results of climate-change simulations were evaluated by observing simulated discharge areas, waterlevel changes, potentiometric-surface configurations, and water budgets. During past-climate conditions, recharge increased in most areas to produce a similarly shaped but higher regional potentialmetric surface. A substantial change to the ground-water-flow system was the exclusion of underflow into the Pahranagat Valley. Under the wetter than present-day conditions that were simulated for the past-climate condition, a ground-water divide developed under the southern end of the Pahranagat Range and isolated the Death Valley regional ground-water-flow system from Pahranagat Valley. Wetter past-climate conditions provided enough ground water in the system to maintain paleolake levels in the northern parts of the model domain and at Lake Manley in Death Valley. Ground-water discharge occurred at most of the observed paleodischarge sites, which indicated that the recharge distributions used in the simulation generally were valid. Large hydraulic gradients in the region were preserved and enhanced under simulated past-climate conditions. The water budget for the model indicated that recharge over the region increased by a factor of about six, relative to simulated present-day recharge. Under these extremely wet conditions, simulated water levels beneath Yucca Mountain rose between 60 and $150 \mathrm{~m}$, which is about 50 to $250 \mathrm{~m}$ below the level of the potential repository.

Under simulated future-climate conditions, both recharge increases and decreases occurred throughout the model domain relative to simulated present-day recharge. The configuration of the potentiometric surface changed only slightly relative to simulated present-day conditions to indicate depressions at discharging playas. These playas, however, were not simulated as discharging as much water as they were during the full-glacial climate and probably would not support perennial lakes. Discharge under globalwarming conditions was simulated as increasing at Ash Meadows, Oasis Valley, and Death Valley. Several playa lakes in the northern and northeastern part of the model domain were simulated as discharging ground water. Under future-climate conditions, large hydraulic gradients were maintained and enhanced in some areas. The water budget indicated that recharge throughout the model increased by a factor of about 1.8 , relative to simulated present-day recharge. Under these climatic conditions, simulated water levels beneath Yucca Mountain rose less than $50 \mathrm{~m}$, which is about 150 to $350 \mathrm{~m}$ below the level of the potential repository.

The limitations to evaluating the effects of climate change on a regional ground-water-flow system by use of a numerical modeling are substantial. Therefore, the simulated effects of climate change should be considered conceptual in nature and should be used only to describe potential relative effects on the regional ground-water-flow system.

\section{REFERENCES CITED}

Bedinger, M.S., Langer, W.H., and Reed, J.E., 1989, Ground-water hydrology, in Bedinger, M.S., Sargent, K.A., and Langer, W.H., eds., Studies of geology and hydrology in the Basin and Range Province, southwestern United States, for isolation of high-level radioactive waste-Characterization of the Death Valley region, Nevada and California: U.S. Geological Survey Professional Paper 1370-F, p. 28-35.

Czarnecki, J.B., 1985, Simulated effects of increased recharge on the ground-water-flow system of Yucca Mountain and vicinity, Nevada-California: U.S. Geological Survey Water-Resources Investigations Report 84-4344, 33 p.

D'Agnese, F.A., Faunt, C.C., Turner, A.K., and Hill, M.C., 1997, Hydrogeologic evaluation and numerical simulation of the Death Valley regional ground-water-fiow system, Nevada and California, U.S. Geological Survey Water-Resources Investigations Report 96-4300, $124 \mathrm{p}$. 
Hill, M.C., 1992, A computer program (MODFLOWP) for estimating parameters of a transient three-dimensional, ground-water-flow model using nonlinear regression: U.S. Geological Survey Open-File Report 91-484, 358 p.

Levy, S.S., 1991, Mineralogic alteration history and paleohydrology at Yucca Mountain, Nevada, in Conference on High-Level Radioactive Waste Management, 2d, Las Vegas, Nev., 1993: Proceedings, American Society of Civil Engineers, p. 477.

Marshall, B.D., Peterman, Z.E., and Stuckless, J.S., 1993, Strontium isotopic evidence for a higher water table at Yucca Mountain-High-Level Radioactive Waste Management: Proceedings of the Fourth International Conference, American Society of Civil Engineers, v. 2, p. 1,948-1,952.
Maxey, G.B., and Eakin T.E., 1949, Ground water in White River Valley, White Pine, Nye, and Lincoln Counties, Nevada: Nevada State Engineer Water Resources Bulletin No. 8, 59 p.

McDonald, M.G., and Harbaugh, A.W., 1988, A modular three dimensional finite-difference ground-water-flow modelS: U.S. Geological Survey Techniques of WaterResources Investigations, book 6, chap. A1, 576 p.

Quade, Jay, Mifflin, M.D., Pratt, W.L., McCoy, W., and Burckle, L., 1995, Fossil spring deposits in the southern Great Basin and their implications for changes in water-table levels near Yucca Mountain, Nevada during Quaternary time: Geological Society of America Bulletin, v. 107, p. 213-230. 